\title{
Overexpression of Glucose Transporters in Rat Mesangial Cells Cultured in a Normal Glucose Milieu Mimics the Diabetic Phenotype
}

\author{
Charles W. Heilig, ${ }^{*}$ Luis A. Concepcion, ${ }^{*}$ Bruce L. Riser, ${ }^{*}$ Svend O. Freytag, ${ }^{\ddagger}$ Min Zhu, ${ }^{\S}$ and Pedro Cortes ${ }^{\star}$ \\ With the technical assistance of Clare C. Hassett, Jeff D. Gilbert, K. S. Sury Sastry, Kathleen O. Heilig, and Janet M. Grondin \\ ${ }^{\S}$ Division of Nephrology and Hypertension, * Department of Medicine, and ${ }^{\ddagger}$ Molecular Biology Research Program, Henry Ford Hospital, \\ Detroit, Michigan 48202
}

\begin{abstract}
An environment of high glucose concentration stimulates the synthesis of extracellular matrix (ECM) in mesangial cell (MC) cultures. This may result from a similar increase in intracellular glucose concentration. We theorized that increased uptake, rather than glucose concentration per se is the major determinant of exaggerated ECM formation. To test this, we compared the effects of $35 \mathrm{mM}$ glucose on ECM synthesis in normal MCs with those of $8 \mathrm{mM}$ glucose in the same cells overexpressing the glucose transporter GLUT1 (MCGT1). Increasing medium glucose from 8 to $35 \mathrm{mM}$ caused normal MCs to increase total collagen synthesis and catabolism, with a net 81-90\% increase in accumulation. MCs transduced with the human GLUT1 gene (MCGT1) grown in $8 \mathrm{mM}$ glucose had a 10-fold greater GLUT1 protein expression and a 1.9, 2.1, and 2.5-fold increase in cell myo-inositol, lactate production, and cell sorbitol content, respectively, as compared to control MCs transduced with bacterial $\beta$-galactosidase (MCLacZ). MCGT1 also demonstrated increased glucose uptake (5-fold) and increased net utilization (43-fold), and greater synthesis of individual ECM components than MCLacZ. In addition, total collagen synthesis and catabolism were also enhanced with a net collagen accumulation 111-118\% greater than controls. Thus, glucose transport activity is an important modulator of ECM formation by MCs; the presence of high extracellular glucose concentrations is not necessarily required for the stimulation of matrix synthesis. (J. Clin. Invest. 1995. 96:1802-1814.) Key words: diabetic nephropathy - glomerulosclerosis • hyperglycemia • extracellular matrix - collagen metabolism
\end{abstract}

\section{Introduction}

The renal glomerular lesion of human and experimental diabetes mellitus is characterized by glomerular hypertrophy $(1,2)$ and

Part of this work was presented in abstract form at the 27th annual meeting of the American Society of Nephrology, 26-29 October 1994, in Orlando, FL.

Address correspondence to Charles W. Heilig, University of Rochester Medical Center, Division of Nephrology, 601 Elmwood Ave., Box 675, Rochester, NY. 14642. Phone: 716-275-3660; FAX: 716-442-9201.

Received for publication 26 October 1994 and accepted in revised form 15 June 1995.

J. Clin. Invest.

(C) The American Society for Clinical Investigation, Inc. 0021-9738/95/10/1802/13 \$2.00

Volume 96, October 1995, 1802-1814 the deposition of extracellular matrix in the form of diffuse thickening of the peripheral basement membrane and mesangial expansion (3). The progressive accumulation of matrix in the mesangial areas, and the associated encroachment on neighboring capillaries with loss of filtration surface area, is considered as the main structural lesion responsible for the relentless decline in glomerular function $(3,4)$. There is persuasive evidence that this critical change may be the result of an altered mesangial cell (MC) ${ }^{1}$ metabolism involving the extracellular matrix. MCs in tissue culture synthesize proteoglycans, fibronectin, laminin, thrombospondin, and various forms of collagens, primarily type IV and type I (5-7). Therefore, a metabolic derangement of these cells in diabetes resulting in the excessive formation and deposition of these matrix components is a likely determinant of mesangial expansion and glomerulosclerosis.

The knowledge on how extracellular matrix synthesis is controlled in MCs is only fragmentary. It is known that the synthetic activity may be stimulated by very diverse factors, notably the mechanical strain induced by distending forces during glomerular hypertension (8) and the action of TGF- $\beta 1$ (9). In diabetes, an obvious injurious alteration could be the continued presence of an abnormally high concentration of extracellular glucose. Recent evidence in humans $(10,11)$ has confirmed early findings in animal studies (12-14) indicating that strict control of glycemia with insulin administration or successful pancreas transplantation may delay the onset and slow the progression of the characteristic mesangial matrix expansion. In addition, it has been amply demonstrated that MCs in tissue culture increase the production of fibronectin, laminin, collagen type IV as well as mRNA levels for these matrix proteins when incubated in the presence of supraphysiological concentrations of glucose $(7,15-18)$. Although it has been suggested that the increase in matrix synthesis may be partially due to the osmolar effect caused by high glucose concentrations (18), most of the evidence accumulated thus far indicates that the change is related to the metabolism of glucose $(16,19,20)$. Glucose enters MCs by a facilitated diffusion process which is independent of insulin action (21). It has, therefore, been proposed that intracellular concentrations of glucose may approach those in the extracellular environment in diabetes $(21)$. High intracellular concentrations of glucose may then increase extracellular matrix formation by activating the polyol pathway, inducing myo-inositol depletion, increasing nonenzymatic glycosylation of proteins, or by generation of the second messengers inositol

1. Abbreviations used in this paper: $\mathrm{MC}$, normal rat mesangial cell; MCGT1, transduced rat MC overexpressing GLUT1 transporter; MCLacZ, transduced MC overexpressing $\beta$-galactosidase. 
triphosphate and diacylglycerol followed by transcriptional activation of extracellular matrix genes $(20,22)$.

We hypothesized that the glucose-induced stimulation of extracellular matrix formation by MCs may not necessarily require the presence of supraphysiological concentrations of glucose if there is an increased transport and thus, excessive bioavailability of this hexose as substrate for metabolism. Except for unique tissues in which glucose is concentrated by an active process involving $\mathrm{Na}^{+}$/glucose cotransporters, i.e., renal proximal tubule and intestinal epithelial cells, glucose enters cells by the passive process of facilitated diffusion. In this process, specific integral membrane proteins, identified as the GLUT family, transport glucose down a concentration gradient. Preliminary work on the identification of glucose transporters in MCs suggests that GLUT1 may be the preponderant isoform (23, 24). This transporter, considered to be responsible for constitutive transport, is known to be regulatable in some tissues. It is also the most ubiquitously distributed of the GLUT isoforms in vivo, and is expressed in virtually all cultured cells (25). The high affinity of GLUT1 for glucose $(26,27)$ ensures that this transporter functions at, or close to, its $V_{\max }$ under normal physiological and diabetic hyperglycemic conditions. In MCs, saturation of glucose uptake has been reported at the $30-35 \mathrm{mM}$ level (21). Therefore, enhanced glucose uptake through GLUT1 may possibly be achieved by raising its extracellular concentration up to $\sim 30 \mathrm{mM}$, by increasing the intrinsic activity of the transporter (28), or through stimulation of GLUT1 expression and/ or translocation from intracellular sites to the plasma membrane (29). However, it has not been determined in MCs if enhanced GLUT1-mediated transport per se is associated with an increased utilization of substrate, i.e., whether transport activity may be an important modulator of glucose metabolism.

To test our hypothesis, we compared the production of extracellular matrix in rat MCs exposed to high glucose concentrations with that in the same cells exposed to physiological levels of extracellular glucose, but overexpressing GLUT1 protein. The results herein reported differentiate the effects of extracellular glucose concentration from those of enhanced intracellular glucose availability and utilization on extracellular matrix formation, providing new insights into the pathogenesis of the glomerular lesion of diabetes.

\section{Methods}

Materials. The purified extracellular matrix components utilized as standards included rat collagen type I (Upstate Biotechnology Inc., Lake Placid, NY), murine collagen type IV, murine laminin (both from Collaborative Research, Inc., Bedford, MA) and rat fibronectin (Chemicon International, Inc., Temecula, CA). The antibodies used were polyclonal anti-rat collagen type I, anti-rat fibronectin, and anti-mouse collagen type IV (Chemicon International, Inc.), and anti-murine laminin (Collaborative Research, Inc.). The polyclonal, rabbit anti-rat GLUT1 antibody used in the identification of GLUT1 was generated to specifically react with a 13 amino acid carboxy terminal peptide of this transporter isoform. The latter were obtained from East Acres Biologicals (Southbridge, MA). The affinity-purified, goat anti-rabbit IgG conjugated to 4-nm gold particles and the silver enhancement system IntenseSE ${ }^{\mathrm{TM}}$ used for the localization of GLUT1 at the light microscopic level, were obtained from Amersham Life Sciences Co. (Little Chalfont, United Kingdom). A monoclonal rabbit anti-rat Ig was used in the immunoblotting analysis of $\beta$-tubulin (Sigma Chemical Co., St. Louis, MO). The human GLUT1 cDNA (vector pSPGT) (30) was kindly provided by Dr. M. Mueckler (Department of Cell Biology and Physiology, Washington University School of Medicine, St. Louis MO). The fibroblast packaging cell line $\Psi$ CRE was kindly provided by Dr. R. Mulligan (Whitehead Institute Biomedical Research, Massachusetts Institute of Technology, Cambridge, MA) and maintained in tissue culture as previously described (31). All MC tissue culture media were based on a special RPMI-1640 formulation lacking glucose, proline, and glutamine (Gibco-93-5044EA; Gibco Laboratories, Grand Island, NY) buffered with $25 \mathrm{mM}$ Hepes. Proline $\mathrm{L}-\left[{ }^{14} \mathrm{C}(\mathrm{U})\right], 286 \mathrm{mCi} / \mathrm{mmol}$; proline $\mathrm{L}-$ $\left[2,3,4,5,-{ }^{3} \mathrm{H}\right], 112 \mathrm{Ci} / \mathrm{mmol}$; hydroxyproline $\mathrm{L}-4-\left[{ }^{3} \mathrm{H}(\mathrm{G})\right], 5.5 \mathrm{Ci} /$ mmol; inulin $\left[{ }^{3} \mathrm{H}(\mathrm{G})\right], 257 \mathrm{mCi} /$ gram; 2-deoxy $\left[1-{ }^{3} \mathrm{H}\right]$ glucose, 30.6 $\mathrm{Ci} / \mathrm{mmol}$ were all purchased from New England Nuclear Research Products (DuPont Co., Wilmington, DE). The purity of the radioisotopic internal standards used in the quantitation of proline and hydroxyproline was established before their use by chromatographic analysis (see below). Additives to tissue culture media were cell culture-tested quality (Sigma Chemical Co). High purity Collagenase VII (Sigma Chemical Co.) was used in the protein-digestion assays. The bacterial myo-inositol dehydrogenase used in the measurement of myo-inositol was obtained from Sigma Chemical Co. The columns used for HPLC were $4.6 \mathrm{~mm}$ $\times 25 \mathrm{~cm}$ Ultrasphere ODS, $5-\mu \mathrm{m}$ particle size (Beckman Instruments Inc., San Ramon, CA).

Tissue culture. MCs were obtained from our cloned line $\left(16 \mathrm{KC}_{2}\right)$ derived from outgrowths of rat glomeruli (Charles River Laboratories, Cambridge, MA) and previously characterized by us (32). In brief, these cells demonstrate a fusiform or stellate appearance, intracellular fibrils, an ability to grow in medium lacking d-valine, growth inhibition when cultured in the presence of heparin or mitomycin, a marked increase in guanosine 5;5'-cyclic monophosphate content upon exposure to atrial natriuretic peptide, and the presence of dense cytoplasmic immunochemical staining for collagen types I and IV, fibronectin, laminin, and thrombospondin. In addition, these cells express the Thy-1 antigen and form "cell hillocks" containing dense extracellular matrix in post confluent cultures. These characteristics have been retained on repeated passage. Finally, we have recently shown that these cells demonstrate the same high sensitivity to phorbol-stimulated neutrophil adhesion and lysis (33) as do early passage MCs, indicating continued and like expression of essential cell surface receptors, including those for CD11/ CD18 molecules.

Except where indicated, MCs were seeded $\left(10,000\right.$ cells $\left./ \mathrm{cm}^{2}\right)$ into 8-cm diameter plastic dishes or $2.5 \mathrm{~cm}$ diameter six-well plates (Corning Glass Works, Corning NY) and grown in the medium described above to which penicillin, streptomycin, $20 \%$ Nu-Serum (Collaborative Research Inc.), $8 \mathrm{mM}$ glucose, $2.05 \mathrm{mM}$ glutamine, and an amount of proline to provide a final concentration of $183 \mu \mathrm{M}$ (including proline contained in $\mathrm{Nu}$-Serum), was added. Considering the high concentrations of glucose commonly occurring in a diabetic milieu $(20-35 \mathrm{mM})$, a glucose concentration of $8 \mathrm{mM}$ was considered as normal. Lower concentrations of glucose were not used because MCs show deficient growth when maintained in the physiological concentration of $5 \mathrm{mM}(7)$. Except for studies to determine growth rates, experiments were terminated $7 \mathrm{~d}$ after seeding, when cultures had just reached confluency. Growth rates were determined in cells seeded in 8-well, $0.79 \mathrm{~cm}^{2}$ glass chamber slides at a density of 12,600 cells $/ \mathrm{cm}^{2}$. Beginning on day 1 , and on alternate days thereafter, cells were counted in four separate wells at each time period.

Preparation of infective virus and transduction of rat MCs. The procedures used were similar to those previously reported (31). Gene transductions were carried out using the pWZLneoMoMuLV retroviral vector (Ariad Pharmaceutical Co., Cambridge, MA). This new vector contains an internal ribosomal entry site from the encephalomyocarditis virus which allows for translation of the GLUTI $(G T 1)$ and neomycin phosphotransferase $\left(n e o^{\mathrm{R}}\right)$ gene products from the same RNA transcript (Fig. 1). This property implies that cells acquiring resistance to the neomycin analog G418 will also express the GLUT1 gene product. Transcription of the discistronic proviral RNA is driven from the Moloney murine leukemia virus (MoMuLV) long terminal repeat. 


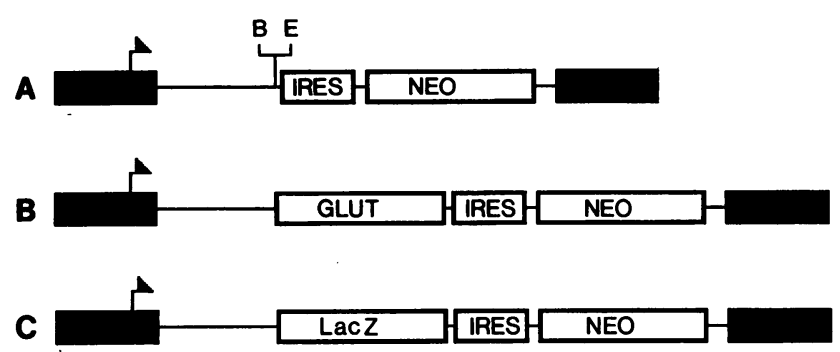

Figure 1. Diagram of the pWZLneo-based retroviral expression vectors. The pWZLneo vector $(A)$ contains an internal ribosomal entry site (IRES) from the encephalomyocarditis virus. It also contains the $n e o^{\mathrm{R}}$ gene (NEO) coding for resistance to G418. The human GLUT1 cDNA is spliced into the BamH1 $[B] / \mathrm{EcoR} 1[E]$ multiple cloning region of the vector $(B)$. To produce a control vector, the bacterial $L a c Z$ cDNA ( LacZ) was similarly spliced into pWZLneo in place of GLUT1 $(C)$. Arrows indicate the transcription initiation site.

The gene which encodes bacterial $\beta$-galactosidase $(L a c Z)$ or the cDNA encoding human GLUTI was spliced into the multiple cloning site of pWZLneo (Fig. 1). Once this was completed, pWZLneoLacZ and pWZLneoGT1 were used to transfect the $\Psi$ CRE fibroblast packaging cell line using a calcium phosphate precipitation method (34). After incubation of the transfected packaging cells for $2 \mathrm{~d}$, the supernatants were removed, filtered through a $0.45-\mu \mathrm{m}$ syringe filter and stored at $-80^{\circ} \mathrm{C}$ until used for transduction of MCs.

Normal MCs $\left(16 \mathrm{KC}_{2}\right)$ in subconfluent cultures were transduced by exposure for $2 \mathrm{~h}$ to the virus-containing supernatant in the presence of $8 \mu \mathrm{g} / \mathrm{ml}$ Polybrene (Sigma Chemical Co.). Cells were then washed and cultured for $2 \mathrm{~d}$ in the growth medium described above before their selection. Selection of stably transduced cells was carried out by two successive incubations, first, in a medium containing $0.25 \mathrm{mg} / \mathrm{ml}$ of the neomycin analog G418 (Sigma Chemical Co.) and then, in a medium in which the G418 concentration was doubled. A surviving clone ex-

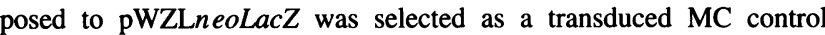
(MCLacZ) due to its high level of $\beta$-galactosidase expression according to the chromogenic dye X-gal (5-bromo-4-chloro-3-indolyl $\beta$-D-galactopyranoside) test (35). A second surviving clone exposed to pWZLneoGTl was selected as a transduced MC overexpressing GLUT1 according to the levels of this product as determined by immunoblotting (see below).

Northern analyses. A standard method with slight modifications was used (36). In brief, total RNA was obtained from cultures of MC using a commercially available kit based on the guanidinium and phenol extraction method (RNA Stat-60; Tel-Test Inc., Friendswood, TX). RNA was denatured in glyoxal/DMSO and 20- $\mu \mathrm{g}$ samples loaded into individual lanes of a $1 \%$ agarose gel made with $10 \mathrm{mM}$ sodium phosphate buffer. Electrophoretic separation was carried out in a circulating buffer gelbox (Hoefer Super Sub; Hoefer Scientific Instruments, San Francisco CA). Gels were then stained with ethidium bromide, destained, and photographed. RNA integrity was confirmed by inspection of the ribosomal RNA bands. Gels were blotted to Genescreen membranes (Dupont NEN Research Products, Boston, MA) and the RNA immobilized by UV irradiation. Blots were then prehybridized, and probed for the GLUT1 isoform, type I collagen, type IV collagen, fibronectin, and the houskeeping gene $\beta$-tubulin using the respective cDNA's (1.66-kb human GLUTI, 1.5-kb $\operatorname{pro\alpha } I(I), 0.7-\mathrm{kb} \operatorname{pro\alpha l}(I V), 0.5-\mathrm{kb}$ fibronectin) The latter were ${ }^{32} \mathrm{P}$-labeled by the Random Hexamer Priming method (PRIME-1 kit; Sigma Chemical Co.). After exposure to Kodak XAR-5 film (Eastman Kodak Co., Rochester, NY) for 3-14 d, the autoradiograms were analyzed by optical scanning densitometry (Scan Master 3+; Howtek Inc., Hudson, NH) using the National Institutes of Health (NIH) Image gel plotting software (NIH Image 1.52; Natl. Technical Information Service, Springfield, VA). Relative quanti- ties of GLUT1 mRNA in MCLacZ and MCGT1 cells were compared after normalization to mRNA for the housekeeping gene $\beta$-tubulin.

Immunoblotting of GLUT1. Immunoblot analysis was carried out according to methods previously described for the study of glucose transporter isoforms with minor modifications (29). $50 \mu \mathrm{g}$ of solubilized protein samples were separated by SDS-PAGE and electrophoretically transferred to Hybond-ECL nitrocellulose membranes (Amersham Corp., Arlington Heights, IL). As primary antibody, the rabbit anti-rat GLUT1 antibody described above was used. The secondary antibody was a horseradish peroxidase anti-rabbit-Ig conjugate (Amersham Corp.). Antigens were identified by a chemiluminescence assay based on the luminol reaction (ECL Western Blot kit, Amersham Life Sciences; Amersham Corp.). Immunoblotting of $\beta$-tubulin was used as a confirmatory method to assure the equal sample loading between gel lanes. Identification of GLUT1 bands was confirmed by preadsorption of antiGLUT1 antiserum with $25 \mu \mathrm{g} / \mathrm{ml}$ of the purified GLUT1 peptide.

Measurement of production of extracellular matrix components, ELISA. In experiments in which specific extracellular matrix components were studied, production was quantified as the total amount accumulated in the tissue culture medium during $24 \mathrm{~h}$ of incubation. At the start of this period, growth medium was changed to one in which $\mathrm{Nu}$ Serum was replaced by $1 \%$ FCS. The presence of Nu-Serum or greater concentrations of FCS were found to result in increased backgrounds and reduced sensitivity of the ELISA. Removal of all serum during the collection period resulted in low recovery rates (3\% or less) of added purified extracellular matrix components. Under the conditions used, recoveries were between 62 and $96 \%$ of added purified extracellular matrix components (ECM). The amount of specific ECM components secreted into the culture medium was quantified by ELISA, using a modification of a procedure previously described (8). Samples of culture medium $(50-100 \mu \mathrm{l})$ were added in triplicate to wells of a 96well ELISA plate (Falcon Labware, Lincoln Park, NJ) and incubated for $18 \mathrm{~h}$ at $4^{\circ} \mathrm{C}$. Purified matrix components, diluted in the same medium, were added $(0.5 \mathrm{ng}-1 \mu \mathrm{g} /$ well $)$ to each assay plate as standards. At the end of this incubation period, the medium was removed, and the unoccupied sites blocked by a 2 -h treatment with $5 \%$ nonfat dry milk (Carnation Co., Los Angeles, CA) in PBS containing 0.05\% Tween. Wells were then washed and incubated for $3 \mathrm{~h}$ with $100 \mu \mathrm{l}$ of rabbit antisera for specific extracellular matrix components. All antisera were tested for specificity, before their use, by immunoblotting, with and without blocking, using the extracellular matrix standards described above. After extensive washing of the wells, an enzyme-linked alkaline phosphatase-labeled goat anti-rabbit IgG (Organon Teknika, Durham, NC) was added and the plates were incubated for an additional 3-h period. This was followed by extensive washing and the addition of a phosphatase substrate solution (Sigma Chemical Co.). Color intensity was measured with a Titertek Multiscan MCC/340 (Flow Laboratories, Inc., McLean, VA), and results analyzed in a curve-fitter computer program (Interactive Microware Inc., State College, PA).

Study of collagen metabolism. Methods previously described (8) were used with modifications. The culture medium was changed $24 \mathrm{~h}$ before the start of the radiolabeling period to a medium lacking proline (except for that contained in Nu-Serum which resulted in a final proline concentration of $40 \mu \mathrm{M}$ ). Preliminary experiments demonstrated no difference in growth rates between cells cultured in $40 \mu \mathrm{M}$ or 0.174 $\mathrm{mM}$ proline over a 14-d period. Radiolabeling was carried out by incubation for 48 or $72 \mathrm{~h}$ in an identical medium, but containing $0.15 \mathrm{mM} \beta$ aminopropionitrile, $210 \mu \mathrm{M}$ ascorbic acid and $183 \mathrm{mM}\left[{ }^{14} \mathrm{C}\right]$ proline $(82.3 \mathrm{mCi} / \mathrm{mmol})$. Previous experiments by us demonstrated that $\left[{ }^{14} \mathrm{C}\right]-$ proline incorporation into collagen increases linearly over a 72-h period of radiolabeling (8) All tissue culture wells were supplemented every $24 \mathrm{~h}$ to provide $140 \mu \mathrm{M}$ fresh ascorbic acid. When the sp act of the cellular proline endogenous pool was determined, $2.5 \mu \mathrm{Ci}$ of $\left[{ }^{3} \mathrm{H}\right]$ inulin/ $\mathrm{ml}$ was added $15 \mathrm{~min}$ before the end of the radiolabeling period as an extracellular fluid marker, and the contents of each well thoroughly mixed. At the termination of the radiolabeling period, medium was rapidly aspirated, the plate placed on ice, and 2-6 ml of cold $0.2 \mathrm{~N}$ 
perchloric acid poured onto the cell layer. The cell layer was not rinsed to remove residual medium, in order to avoid losses of intracellular free proline. In experiments done in 6-well plates, the media and cell layers of 6 wells were pooled as one sample for analysis.

Total protein contained in the medium samples was precipitated in $75 \%$ ethanol at $-5^{\circ} \mathrm{C}$, and the supernatant analyzed for $\left[{ }^{3} \mathrm{H}\right]$ inulin concentration. After the addition of $89 \mu \mathrm{Ci}\left[{ }^{3} \mathrm{H}\right]$ proline as internal standard, medium supernatants were filtered in Centricon ${ }^{\mathrm{TM}}-3$ filters (Amicon Co., Danvers, MA) and amino acids were separated by solid phase extraction using AG50W-X8 $\left(\mathrm{H}^{+}\right)$columns (Poly-Prep ${ }^{\circledR}$; Bio Rad Laboratories, Richmond, $\mathrm{CA}$ ) and $6 \mathrm{~N} \mathrm{NH} \mathrm{NH}_{4} \mathrm{OH}$ as eluant. After $\mathrm{NH}_{4} \mathrm{OH}$ removal under vacuum (Speed-Vac concentrator; Savant Instruments Inc., Farmingdale, NY), purified amino acids were resuspended in $0.1 \mathrm{~N} \mathrm{HCl}$ for the subsequent determination of $\left[{ }^{14} \mathrm{C}\right]$ hydroxyproline, total proline, proline sp act, and calculation of the proline and $\left[{ }^{14} \mathrm{C}\right]$ proline $/\left[{ }^{3} \mathrm{H}\right]$ inulin ratios.

Net collagen accumulation in the medium was estimated by two independent methods. The first measurement was obtained according to the ${ }^{14} \mathrm{C}$ incorporation into protein-associated hydroxyproline (8). In this method, the medium protein precipitate was hydrolyzed under vacuum with $6 \mathrm{~N} \mathrm{HCl}$ at $110^{\circ} \mathrm{C}$ for $18 \mathrm{~h}$ and amino acids separated as above by solid phase extraction after the addition of $3.32 \mu \mathrm{Ci}\left[{ }^{3} \mathrm{H}\right]$ hydroxyproline as an internal standard. These purified amino acids were subsequently analyzed for measurement of ${ }^{14} \mathrm{C}$ incorporation into proline and hydroxyproline. The second method was based on the amount of total ${ }^{14} \mathrm{C}$ incorporated into collagenase-digestible protein $(37)$. In this method, after completion of the radiolabeling period, $1 \mathrm{ml}$ of medium was mixed with $330 \mu$ l of a proteinase inhibitor solution (providing per milliliter: $3 \mu \mathrm{mol}$ PMSF, 0.1 mmol EDTA, $40 \mu \mathrm{mol} N$-ethylmaleimide). Medium protein was precipitated and the pellet washed five times with cold $10 \%$ TCA. This precipitate was then resuspended in $1 \mathrm{~N} \mathrm{NaOH}$, incubated for $10 \mathrm{~min}$ at $37^{\circ} \mathrm{C}$, and the solution neutralized with $1 \mathrm{~N}$ $\mathrm{HCl}$. After adjusting the $\mathrm{pH}$ to 7.5 with $1 \mathrm{~N}$ Tris buffer solution, PMSF and $N$-ethylmaleimide were added in the same amounts as before, and $\mathrm{CaCl}_{2}$ added to provide a final $5 \mathrm{mM}$ solution. For enzymatic digestion, the sample was divided into two equal portions and $140 \mathrm{U} / \mathrm{ml}$ of collagenase added to one of them, while the other was used as a control. After incubation for $2 \mathrm{~h}$ at $37^{\circ} \mathrm{C}$, the undigested protein was removed by precipitation with $10 \%$ TCA and $0.5 \%$ tannic acid. Finally, the ${ }^{14} \mathrm{C}$ radioactivity in the supernatants and protein precipitate was measured and the radiolabel incorporation into collagenase-digestible and collagenase-resistant protein determined from the difference between the treated and nontreated samples.

Immediately after addition of $0.2 \mathrm{~N}$ perchloric acid, cell layers were scraped, briefly homogenized in the cold and the precipitates and acidsoluble supernatants separated by centrifugation. To measure the proline endogenous pool, these supernatants were neutralized at $4^{\circ} \mathrm{C}$ with $1 \mathrm{~N}$ $\mathrm{KOH}$ to $\mathrm{pH} 7.0$ and the concentration of $\left[{ }^{3} \mathrm{H}\right]$ inulin determined before the addition of $45 \mu \mathrm{Ci}$ of $\left[{ }^{3} \mathrm{H}\right.$ ] proline as an internal standard. The amino acids contained in this acid-soluble cell extract were separated by solid phase extraction as above, and lyophilized before measurement of cell layer-associated free $\left[{ }^{14} \mathrm{C}\right]$ hydroxyproline, free proline, and proline $\mathrm{sp}$ act. Because values for the ratios proline $/\left[{ }^{3} \mathrm{H}\right]$ inulin and $\left[{ }^{14} \mathrm{C}\right]$ proline/ $\left[{ }^{3} \mathrm{H}\right]$ inulin in the medium from the same sample were known, the amount of proline and $\left[{ }^{14} \mathrm{C}\right]$ proline contributed by residual medium in the cell layer could be estimated in individual samples according to the amount of $\left[{ }^{3} \mathrm{H}\right]$ inulin measured in the cell layer acid extract, as done in previous studies (8). The cell layer's perchloric acid precipitate was lipid-extracted and consecutively subjected to alkaline and acid hydrolysis for the measurement of total RNA, DNA, and the separation of protein (38). The final protein precipitate was hydrolyzed as described above, $\left[{ }^{3} \mathrm{H}\right]$ hydroxyproline internal standard added, and amino acids purified and separated for the quantitation of ${ }^{14} \mathrm{C}$ incorporation into proline and hydroxyproline.

Measurement of 2-deoxyglucose uptake rates and kinetics. The uptake of glucose was determined by using the nonmetabolizable analog 2-deoxy-D- $\left[1-{ }^{3} \mathrm{H}\right]$ glucose according to a modification of the method of
McClain et al. (39). MCs were seeded in $35 \mathrm{~mm}$ diameter wells at a density of 42,000 cells $/ \mathrm{cm}^{2}$ and allowed to attach for $2 \mathrm{~h}$. After removal of the medium and rinsing with PBS, cultures were incubated in glucosefree PBS for $30 \mathrm{~min}$ and then, this buffer solution replaced with one containing $0.1 \mu \mathrm{Ci} / \mathrm{ml}$ of the radiolabeled analog $(3.27 \mathrm{nM}) .1 \mathrm{ml}$ of this solution was added per well and the samples were incubated for 5 min. After this, the unincorporated radioisotope was rapidly removed by washing the cell layer with cold PBS and cells were harvested for counting by trypsinization. To determine the kinetics of glucose uptake for the two different cell types, similar experiments to those described above were carried out using 13 different media concentrations of Dglucose between 0 and $24 \mathrm{mM}$. Results were expressed per milligram protein as determined in parallel culture plates. Lineweaver-Burk double reciprocal plots were used for the calculation of $K_{\mathrm{m}}$ and $V_{\max }$

Chromatography. Amino acids were analyzed as their precolumndansylated derivatives by reverse phase HPLC as previously described (8). In brief, derivatization was carried out at room temperature at $\mathrm{pH}$ 9.0 in a $3.5 / 1$ molar ratio of 5-dimethylaminonaphthalene-1-sulfonyl (dansyl) chloride/amino acids for $20 \mathrm{~h}$. Analyses were performed using a Beckman 344 HPLC (Beckman Instruments) and 0.05 M monosodium phosphate/acetic acid buffer, $\mathrm{pH} 7.0$, as the initial eluant and acetonitrile as the final eluant. Sample size was 46 and $355 \mathrm{nmol}$ of amino acid residues for analysis of samples from supernatants and protein precipitates, respectively. A linear gradient between 10 and $25 \%$ acetonitrile at $1.5 \mathrm{ml} / \mathrm{min}$ flow rate resulted in optimal separation of hydroxyproline and proline in $46 \mathrm{~min}$. The column effluent was monitored for fluorescence (Spectroflow 980 fluorescence detector; Applied Biosystems, Ramsey, NJ) at $350 \mathrm{~nm}$ excitation and $470 \mathrm{~nm}$ emission wavelengths, and $0.3 \mathrm{ml}$ fractions collected for measurement of ${ }^{3} \mathrm{H}$ and ${ }^{14} \mathrm{C}$ content. The recovery of the $\left[{ }^{3} \mathrm{H}\right]$ proline and hydroxyproline was $43-77 \%$ and $70-96 \%$, respectively.

All radioactivity measurements were carried out using Optiphase Hisave II (LKB Scintillation Products, Loughborough, United Kingdom) as scintillator in a 3-channel liquid scintillation counter providing quench compensation (Beckman LS-3801; Beckman Instruments).

Immunogold labeling. The presence of cell-associated GLUT1 was studied by light microscopic examination of immunogold silver-stained samples of acetone-fixed MC cultures (40). Cells were seeded in 0.79 $\mathrm{cm}^{2}$ wells at 12,600 cells $/ \mathrm{cm}^{2}$. At $5 \mathrm{~d}$ of growth the medium was aspirated and the cell layer washed with PBS followed by fixation in acetone for $10 \mathrm{~min}$. After air drying, the specimens were immersed in PBS for $20 \mathrm{~min}$, placed in $1 \%$ BSA for $1 \mathrm{~h}$ at room temperature and then incubated with the anti-GLUT1 antibody. After extensive washing in PBS, the gold-conjugated secondary antibody was applied for $2 \mathrm{~h}$ at $25^{\circ} \mathrm{C}$ and the specimens washed again in PBS. Finally, samples were treated with glutaraldehyde and the labeling enhanced with the Amersham silver solution following the manufacturers instructions. Light microscopic examination was made in Mayer's hematoxylin-counterstained specimens.

Chemical measurements. Myo-Inositol was measured spectrophotometrically by following the reduction of NAD during the inositol dehydrogenase reaction (41). D-Sorbitol was analyzed by modification of a colorimetric method (42) based on the sorbitol dehydrogenase reaction and the NADH-induced reduction of iodonitrotetrazolium chloride (Test-combination D-sorbitol/Xylitol; Boehringer Mannheim Biochemicals, Indianapolis, IN). Lactate was measured according to the NADH formed during the lactate dehydrogenase reaction utilizing a commercially available kit (Sigma Diagnostics Lactate; Sigma Chemical Co.). D-glucose was measured by a colorimetric method based on the glucose oxidase-peroxidase reaction (glucose procedure no. 510 kit; Sigma Chemical Co.). Protein was measured by the method of Lowry using BSA as the standard.

RNA was measured by the orcinol reaction for quantitation of its ribose content. With this method $1 \mu \mathrm{g}$ of yeast RNA (Type I; Sigma Chemical Co.) is equivalent to $0.6 \mu \mathrm{g}$ of ribose (43). DNA was measured by its ultraviolet absorption by a 2 wavelength ratio method (44) using calf thymus DNA (Type I; Sigma Chemical Co.) as reference 


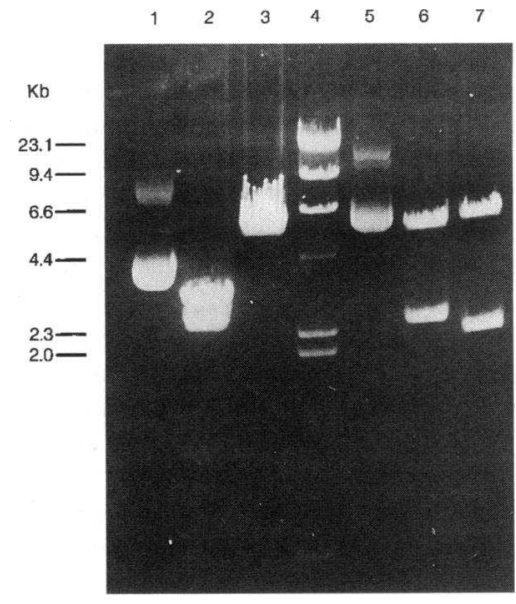

Figure 2. Ethidium bromide-stained agarose gel electrophoresis bands depicting the construction of the PWZLneo vector. In lane $l$ is the uncut donor vector PSPGT. In lane 2, this vector has been cut with BamH1 to remove the $2.6 \mathrm{~kb}$ GLUT1 cDNA insert. In lane 3, EcoR1 digestion linearizes the vector. Lane 4 contains the $\lambda$ Hind III size markers. Lane 5 demonstrates the final uncut product pWZLneoGLUT1 re-

sulting from splicing of the GLUT1 cDNA into the BamH1 cloning site of pWZLneo. Lane 6 demonstrates the product of a BamH1 digest of pWZLneoGLUT1 to confirm the presence of the $2.6 \mathrm{~kb}$ GLUT1 insert. The $5^{\prime} \rightarrow 3^{\prime}$ orientation of GLUT1 inside the pWZLneo vector is confirmed in lane 7, where digestion with EcoR1 results in the expected $6.0 \mathrm{~kb}$ and $2.2 \mathrm{~kb}$ bands.

standard. Total amino acids were quantified by a modified ninhydrin method (45) using L-leucine as the standard.

Expression of results and statistical analyses. Depending on the type of experiment, results were expressed as per unit protein in the cell layer or as per cell or DNA, and presented as means \pm SEM. With the methods utilized, the cellular content of DNA was $27.4 \pm 1.74 \mathrm{pg}$. The optical density of the bands in the immunoblotting analyses was expressed in arbitrary units and the final results presented as percent change from control values. The net collagen accumulation in the medium and in the cell layer was expressed according to the amount of $\left[{ }^{14} \mathrm{C}\right]$ proline incorporated into protein-associated $\left[{ }^{14} \mathrm{C}\right]$ hydroxyproline, while the incorporation into protein-associated $\left[{ }^{14} \mathrm{C}\right]$ proline was considered as an index of total protein synthesis. In the alternate method, net collagen accumulation in the medium was measured as the total ${ }^{14} \mathrm{C}$ radioactivity incorporated into collagenase-digestible protein and total protein synthesis as the ${ }^{14} \mathrm{C}$ radioactivity incorporated into collagenaseresistant protein. Collagen breakdown was estimated as the total newly formed free hydroxyproline, i.e., the sum of the medium and cell layer $\left[{ }^{14} \mathrm{C}\right]$ hydroxyproline detected as a free amino acid. Total collagen synthesis was quantified as the total $\left[{ }^{14} \mathrm{C}\right]$ hydroxyproline formed, free or protein-associated, in the whole tissue culture sample. All results were adjusted for recovery rates of pure radiolabeled internal standards. Incorporation values were individually corrected in each sample for the $\mathrm{sp}$ act of the medium free proline at the completion of the labeling period, and presented as nanomoles of proline incorporated per $24 \mathrm{~h}$ of radiolabeling. Differences between groups were evaluated using Student's $t$ test for nonpaired samples and the distribution of $t$ in a two-tailed test. Since previous studies demonstrated that collagen synthesis may be inversely related to tissue culture cell density in subconfluent cultures (8), significant differences in incorporation results were confirmed by analysis of covariance. In this analysis, to remove the effect of differences in cell content, the total amount of DNA in the sample was added as a regressor affecting the dependent variable (incorporation).

\section{Results}

Gene construction and characterization of LacZ and GLUT1 expression vectors. Construction of the pWZLneo expression vector is depicted in Fig. 2. The GLUT1 cDNA was first removed from the vector PSPGT by cutting with BamH1 and then

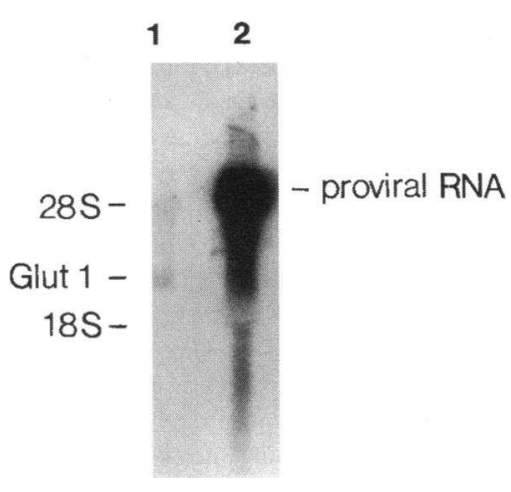

Figure 3. Northern analysis of transduced mesangial cells. Total RNA was isolated from confluent cultures of MCLacZ (lane 1) or MCGT1 (lane 2) cells 7 $\mathrm{d}$ after seeding. The Northern blot was probed with a ${ }^{32} \mathrm{P}$-labeled human GLUT1 cDNA fragment to demonstrate GLUT1 mRNA. The exogenous GLUT1 mRNA derived

from pWZLneoGLUT1 in MCGT1 cells is included in the $5.6 \mathrm{~kb}$ band of proviral RNA. The endogenous GLUT1 mRNA of MCGT1 cells (Glut 1) appears at the $3.0 \mathrm{~kb}$ level, although it is obscured by the intense signal from the proviral RNA. MCLacZ cells contain only the $3.0 \mathrm{~kb}$ endogenous GLUT1 mRNA.

spliced into the BamH1 cloning site of pWZLneo. Digestion with EcoR1 confirmed the $5^{\prime} \rightarrow 3^{\prime}$ orientation of the insert.

Expression of GLUT1 mRNA and GLUT1 protein. The G418-resistant LacZ transduced MCs expressed large quantities of $\beta$-galactosidase as shown by the $\mathrm{X}$-gal staining test. In addition these cells, grown in $8 \mathrm{mM}$ glucose, expressed substantial amounts of GLUT1 mRNA (Fig. 3). The level of GLUT1 mRNA increased 18-fold in MCGT1 cultured in the same conditions. MCLacZ also expressed the glucose transporter protein, as demonstrated by immunogold localization and immunoblot analysis (Figs. 4 and 5). As compared to these controls, MCGT1 cells cultured in the same glucose concentration demonstrated a 10-fold enhanced expression of GLUT1 protein that was evident in immunoblotting analyses (Figs. 5 and 6) and in immunogold studies (Fig. 4). The latter also demonstrated that this change was generalized and of a similar magnitude in all the MCGT1 cells. In addition, this overexpression was still present at similar levels after $3 \mathrm{mo}$ in cultures maintained in the same normal glucose concentration, as demonstrated by immunoblot analysis (data not shown).

Glucose transport and kinetics. Preliminary experiments demonstrated that, under the conditions selected, 2-deoxyglucose uptake increased linearly with time over the first $10 \mathrm{~min}$ of incubation. As compared to the MCLacZ controls, the 5-min uptake of the glucose analog in MCGT1 cells was markedly augmented (Fig. 7), suggesting a greatly enhanced entry of glucose in cells overexpressing GLUT1. In support of these findings, kinetic analyses revealed a 4.3-fold higher $V_{\max }$ in MCGT1 vs MCLacZ cells $(P<0.001)$ (Fig. 8$)$. In addition, the $K_{\mathrm{m}}$ values for the rat (MCLacZ) and human (MCGT1) transporters were similar $(P>0.2)$ and within the expected range of values (Fig. 8).

Cell growth. Exposure of normal MCs to $35 \mathrm{mM}$ glucose for $7 \mathrm{~d}$ resulted in a moderately diminished proliferating activity and slight cell hypertrophy, as shown by a $17 \%$ significantly lower DNA content and an $8 \%$ significantly higher RNA/DNA ratio in cells cultured in high glucose concentration (Table I). Changes similar to these, but greatly exaggerated, were observed in MCGT1 cells cultured in normal glucose concentrations. At the end of the same observation period, cultures of MCGT1 cells demonstrated a 33\% lower content of DNA and 


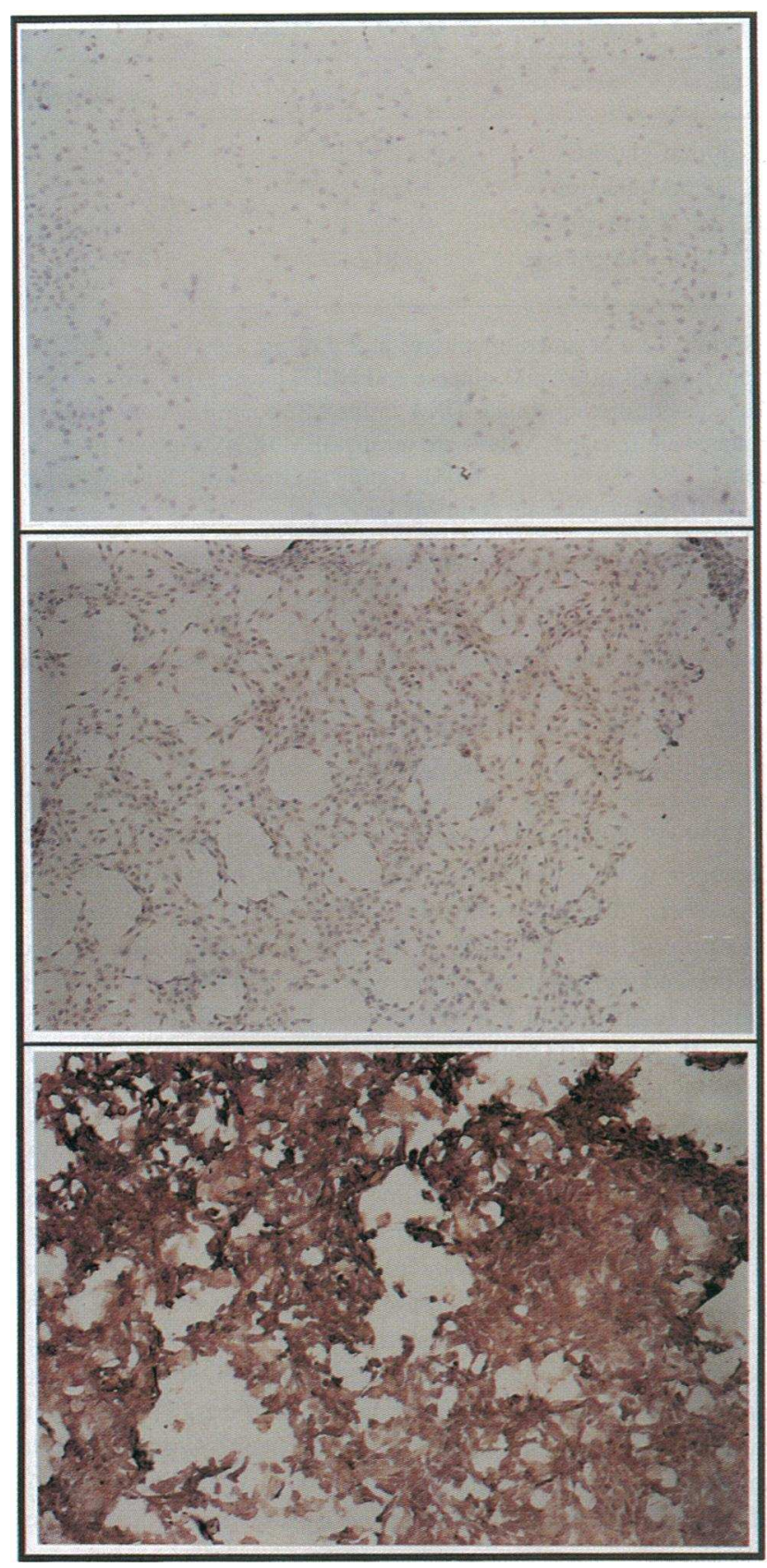

Figure 4. Immunogold-silver labeling of cell-associated GLUT1 in transduced mesangial cells. The cell layer of MCLacZ (middle panel) or MCGT1 cultures (lower panel) were incubated with specific antiGLUT1 antibody or nonimmune serum (MCGT1 cells, top panel) as a control. The level of GLUT1 expression is demonstrated according to the intensity of the brown silver staining. Original magnification was 40 .

a 38\% higher RNA/DNA ratio than their MCLacZ controls (Table I). The lower proliferative activity of the MCGT1 cultures as compared to MCLacZ cultures was also suggested by the different shape of the growth curves obtained over a 15-d period of culture (Fig. 9). Therefore, the inhibition of replication and hypertrophic effects associated with exposure of normal MCs to high extracellular glucose concentrations were also present under normal glucose concentration in cells with en-

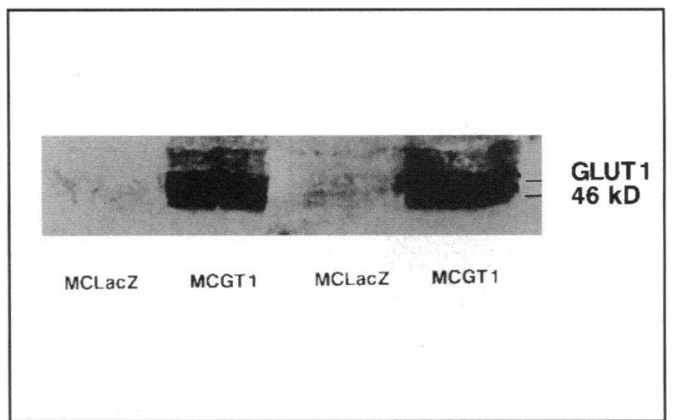

Figure 5. GLUT1 expression in transduced mesangial cells. Duplicate immunoblot analyses of 50- $\mu \mathrm{g}$ protein samples, obtained from the cell layers of confluent cultures, are shown. GLUT1 protein is demonstrated in MCLacZ and MCGT1 cells as single bands of very different intensity migrating at $48 \mathrm{kD}$.

hanced glucose transport, albeit these changes were greatly magnified.

Metabolic characteristics. To determine if the enhanced glucose uptake induced by the overexpression of GLUT1 transporter was also associated with an increased metabolism of the hexose, lactate and sorbitol contents were measured as indices of substrate utilization. Under the same conditions of normal glucose concentration as above, lactate release into the medium as well as that associated with the cell layer were 2.5- and 2.2-fold greater, respectively, in MCGT1 cultures than in their MCLacZ counterparts (Table II). In similar experiments, cell sorbitol content was also increased 2.1-fold in MCGT1 cultures (Table II). Interestingly, this sorbitol accumulation was also associated with a significantly increased content of cell myoinositol (Table II). These findings suggest that an increased glucose transport in MCs is linked to the greater metabolism of this sugar, at least via the glycolytic and polyol pathways.

Production of extracellular matrix components. The secretion into the medium of specific extracellular matrix components was studied in MCGT1 cells to establish whether enhanced glucose transport, albeit in an environment of normal glucose concentration, could effectively stimulate the synthesis of the main components of mesangial matrix. As compared to their MCLacZ controls, MCGT1 cells secreted significantly

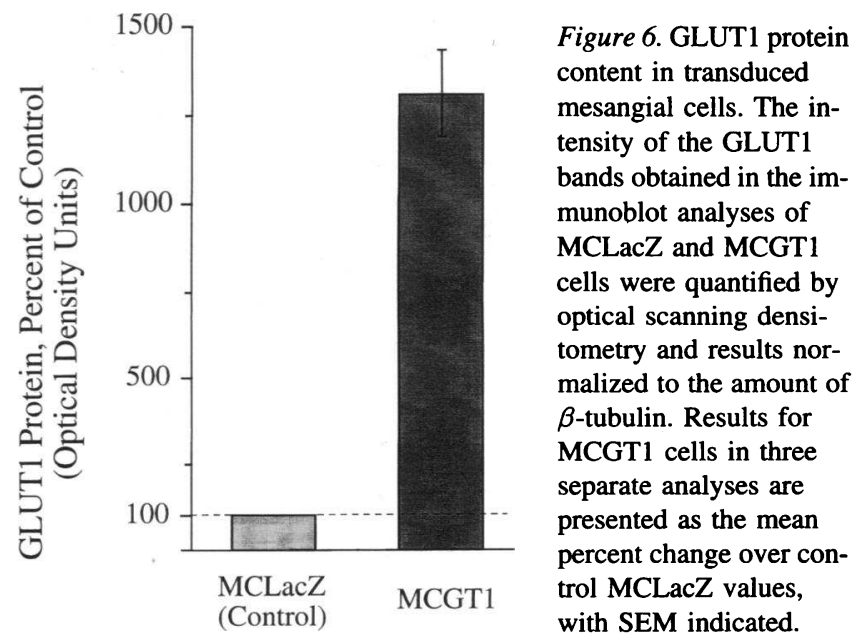




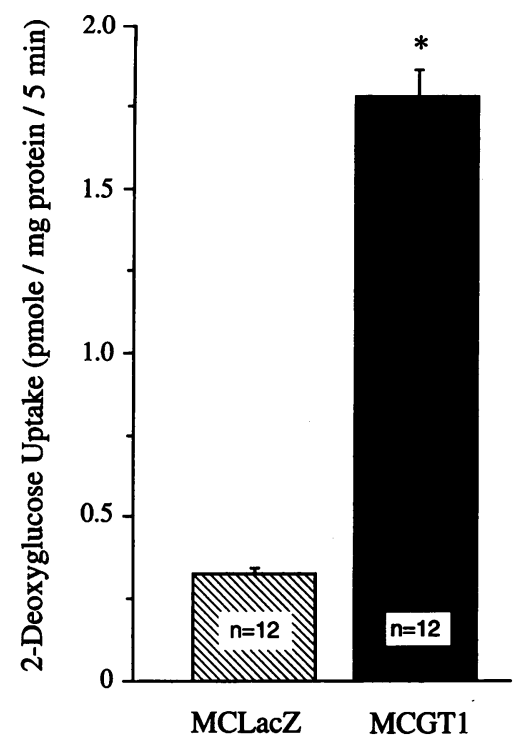

Figure 7. Uptake of 2deoxyglucose in transduced mesangial cells. Studies were carried out in cultures preincubated in a glucose-free buffer solution before the addition of 2-deoxy-D-[1-

$\left.{ }^{3} \mathrm{H}\right]$ glucose. Results are presented as the mean \pm SEM.

more collagen type I, collagen type IV, fibronectin, and laminin (Fig. 10).

Northern analyses for individual matrix components demonstrated fibronectin mRNA as a single band and collagens I and IV as their characteristic doublets $(46,47)$. Differences in the secretion of extracellular matrix components likely resulted from increased synthesis in MCGT1 cells because their respective mRNAs were elevated $43-80 \%$ as compared with their MCLacZ controls (Fig. 11).

Collagen metabolism in conditions of high glucose concentration and high glucose transport activity. To analyze in detail how collagen metabolism may be altered by the presence of high glucose concentrations or by the enhanced glucose transport, the synthesis and catabolism of collagen was studied in normal MCs cultured in 8 or $35 \mathrm{mM}$ glucose and in transduced MCs cultured in $8 \mathrm{mM}$ glucose. The incorporation rate of radiolabeled amino acid precursor into protein is strongly influenced by changes in the sp act of its endogenous pool. Therefore,

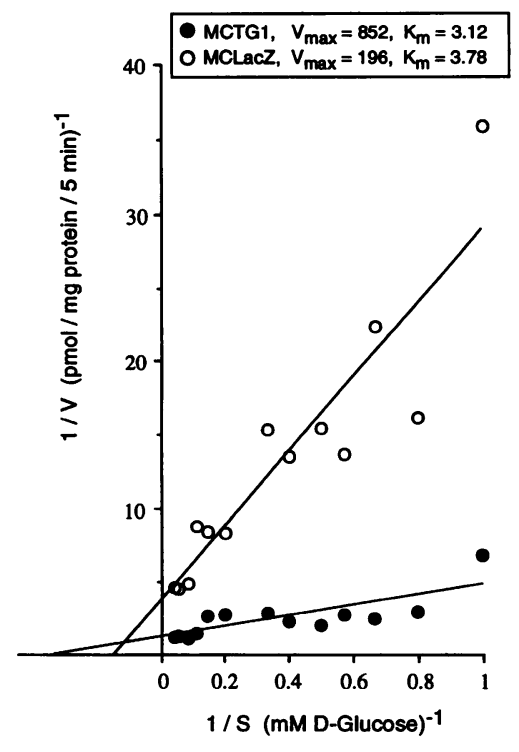

Figure 8. Kinetic analyses of 2-deoxyglucose uptake in transduced mesangial cells. Studies were carried out as in Fig. 7 except that media total glucose concentration was varied between 0 and $24 \mathrm{mM}$. Each data point represents the mean value of six separate determinations. Results presented are the combined values from three separate experiments. $\mathrm{Li}$ neweaver-Burk double reciprocal plots were calculated to determine the $K_{\mathrm{m}}$ and $V_{\max }$ values for each of the two cell types.
Table I. Growth of MC and MCGT1 or MCLacZ*

\begin{tabular}{lcc}
\hline & \multicolumn{1}{c}{ DNA $(\mu \mathrm{g})$} & RNA $(\mu \mathrm{g}) / \mathrm{DNA}(\mathrm{mg})$ \\
\hline MC 8 mM glucose & $96.29 \pm 5.17$ & $136.3 \pm 2.22$ \\
MC 35 mM glucose & $84.00 \pm 1.67^{\ddagger}$ & $146.8 \pm 3.5^{\mathbf{3}}$ \\
MCLacZ 8 mM glucose & $91.32 \pm 1.57$ & $151.8 \pm 2.7$ \\
MCGT1 $8 \mathrm{mM}$ glucose & $60.87 \pm 1.72^{\|}$ & $210.2 \pm 1.7^{\|}$ \\
\hline
\end{tabular}

* Results were obtained in cultures at $7 \mathrm{~d}$ of growth. To compare the relative effects of $35 \mathrm{mM}$ glucose and GLUT1 overexpression, experiments demonstrating similar DNA in the MC control and MCLacZ groups were selected. Values are mean \pm SEM of six samples in each group. ${ }^{\ddagger} P=0.047 ;{ }^{\S} P=0.031$, significant from MC, $8 \mathrm{mM}$ glucose. " $P<0.0001$, significant from MCLacZ.

initial experiments were done to evaluate the effect of medium glucose concentration on medium and endogenous pool proline sp act. At the completion of the incubation period, medium proline sp act was 88 and $94 \%$ of the initial value in media containing 8 and $35 \mathrm{mM}$ glucose, respectively. The difference between these two groups was significant $(8 \mathrm{mM}$, $133,717 \pm 6,068, n=6 ; 35 \mathrm{mM}, 149,000 \pm 3,810 \mathrm{dpm} / \mathrm{nmol}$ proline, $n=6, P<0.0001$ ). These changes in medium proline sp act were mirrored by those occurring in the cellular endogenous pool of proline. Thus, at the end of the incubation period proline endogenous pool sp act was also significantly lower in samples incubated in $8 \mathrm{mM}$ glucose $(8 \mathrm{mM}, 87,468 \pm 5,389, n$ $=6 ; 35 \mathrm{mM}, 102,650 \pm 7,516 \mathrm{dpm} / \mathrm{nmol}$ proline, $n=6, P$ $=0.0004$ ). Since calculation of incorporation results according to the sp act of proline in the endogenous pool or in the incubation media did not alter the differences between groups, all results were expressed according to the final sp act of free proline in the sample's incubation medium.

In normal MCs, exposure to $35 \mathrm{mM}$ glucose for a period of $12 \mathrm{~d}$ induced a $69 \%$ increase in collagen synthesis (Table III). This change was associated with an $80-90 \%$ greater net accumulation of newly formed collagen in the medium, as measured by two independent radiolabeling methods. There was an inverse relationship between the amount of DNA in the sample and collagen accumulation $(P=0.0005)$. When the effect of different DNA content was removed by analysis of covariance,

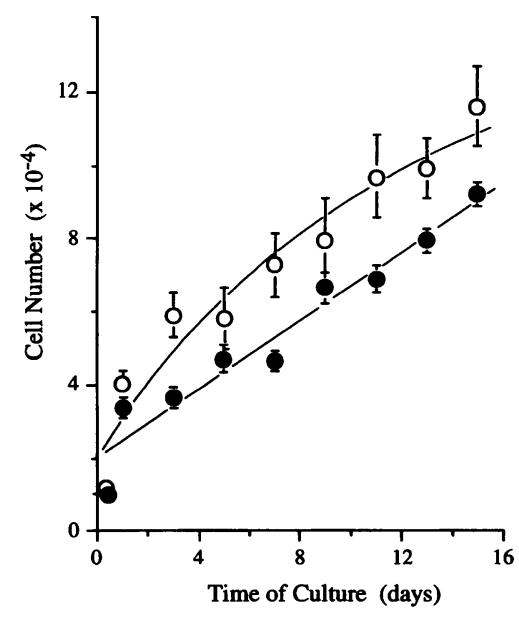

Figure 9. Growth rate of transduced mesangial cells. Cells were counted at different growth periods in continuous MCLacZ (O) and MCGT1 ( $\bullet$ ) cultures. Data points represent the mean \pm SEM of four samples. 
Table II. Metabolic Characteristics of MCGT1 or MCLacZ Grown in the Presence of Normal Glucose Concentrations*

\begin{tabular}{lcr}
\hline & MCLacZ & MCGT1 \\
\hline & $n=4$ & $n=4$ \\
& & \\
Lactate production & & \\
$\quad$ (mmol/mg protein per 72 h) & & \\
Medium & $4.16 \pm 0.57$ & $10.58 \pm 0.85^{\ddagger}$ \\
Cell & $1.66 \pm 0.10$ & $3.66 \pm 0.21^{8}$ \\
Cellular sorbitol content & $6.54 \pm 1.26$ & $14.07 \pm 1.33^{\ddagger}$ \\
$\quad$ (nmol/mg protein) & & \\
$\begin{array}{l}\text { Cellular myo-inositol content } \\
\text { (nmol/mg protein) }\end{array}$ & $18.4 \pm 1.41$ & $35.65 \pm 2.02^{8}$ \\
& & \\
\hline
\end{tabular}

* Results were obtained in cultures grown to confluency in $8 \mathrm{mM}$ glucose. Values are mean \pm SEM. ${ }^{\ddagger} P<0.005 ;{ }^{8} P<0.0001$.

the differences between groups were still significant ( $P$ $=0.0001)$. In addition, the accumulation of collagen in the cell layer (much lower than into the medium due to the presence of $\beta$-aminopropionitrile) was also increased by $68 \%$. The increment in collagen synthesis caused by glucose was also associated with a 59\% greater catabolism. Although the fraction of the collagen produced undergoing catabolism was significantly lower in high glucose concentration cultures, comparison of the magnitude of the changes in synthesis and catabolism reveal that the main cause for net collagen accumulation was enhanced formation.

The increase in collagen accumulation in the incubation medium coincided with a stimulation in overall protein secretion as measured by the two radiolabeling methods (Table III) (collagenase-resistant protein: $8 \mathrm{mM}, 42.6 \pm 1.4, n=8 ; 35 \mathrm{mM}$, $79.5 \pm 3.9 \mathrm{nmol}$ proline $/ \mathrm{mg} \mathrm{DNA} / 24 \mathrm{~h}, n=8, P<0.0001$ ). However, the change in collagen formation was significantly greater than that for total protein (Table III).

At the completion of the labeling period, medium proline sp act did not differ in the two groups of transduced cells cultured in $8 \mathrm{mM}$ glucose (MCLacZ, 205,288 $\pm 3,030, n=6$;

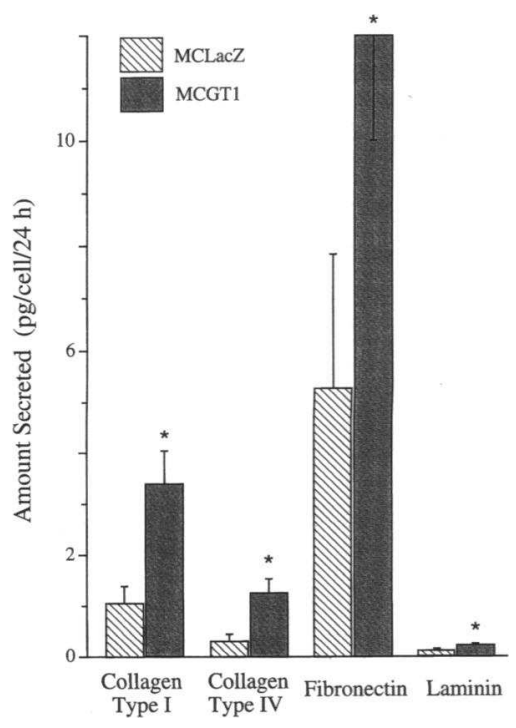

Figure 10. Secretion into the medium of extracellular matrix components in transduced mesangial cells. The amounts secreted in $24 \mathrm{~h}$ by MCGT1 cultures and their MCLacZ controls are presented. Values are means \pm SEM, $n=6 . P$ $<0.0001$.

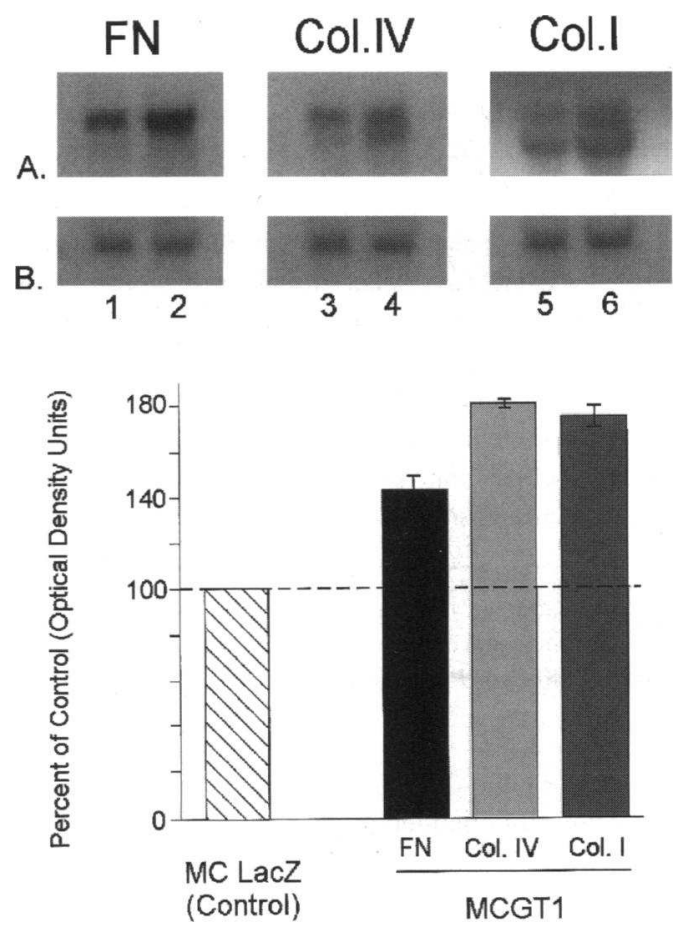

Figure 11. Northern analysis of individual extracellular matrix components in transduced mesangial cells. $20 \mu \mathrm{g}$ of total RNA isolated from MCLacZ (lanes 1, 3, and 5) or MCGT1 (lanes 2, 4, and 6), were loaded to each lane for electrophoretic separation. Blots were probed for fibronectin $(F N)$, type IV collagen ( $\mathrm{Col} . \mathrm{IV}$ ) and type I collagen (Col. I) using their respective ${ }^{32} \mathrm{P}$-labeled cDNAs $(A)$. The bar graph indicates quantitation of Northern analyses for matrix components by optical scanning densitometry, with results normalized to the amount of mRNA for the housekeeping gene $\beta$-tubulin $(B)$. Results for MCGT1 cells in three separate analyses are presented as the mean percent of control MCLacZ values, with SEM indicated.

MCGT1, 200,230 $\pm 3,290, n=6)$. MCGT1 cells demonstrated a $109 \%$ increase in total collagen synthesis, associated with a $111-117 \%$ greater net accumulation, as compared to their MCLacZ controls (Table IV). As in experiments in normal mesangial cells, there was a significant effect of the sample's DNA content on the collagen accumulated $(P=0.005)$. After this effect was eliminated in an analysis of covariance, the differences between groups were still significant $(P=0.015)$. This augmented collagen accumulation in the medium was part of an overall enhancement in protein synthesis as suggested by results from the two methods used in this study (Table IV) (collagenase-resistant protein: MCLacZ, 45.6 $\pm 13.3, n=6$; MCGT1, 82.8 $\pm 10.7 \mathrm{nmol}$ proline $/ \mathrm{mg}$ DNA/24 h, $n=6, P$ $=0.055)$. Nevertheless, as shown above in normal cells, the synthesis of collagen was particularly stimulated in MCGT1 cells (Table IV). The amount of collagen accumulated in the cell layer was also increased in MCGT1 cells by $64 \%$ of the value for MCLacZ cells. Also, as shown in normal MCs, the greater collagen synthesis in MCGT1 cells was associated with a marked increase in collagen catabolism. However, the fraction of collagen produced which was catabolized was similar in both types of cells, therefore, the net collagen accumulation demonstrated in medium and cell layer of MCGT1 cultures was fully attributable to an increased rate of synthesis. 


\begin{tabular}{llc}
\hline & $\begin{array}{c}8 \mathrm{mM} \\
\text { Glucose }\end{array}$ & $35 \mathrm{mM}$ Glucose \\
\hline & $n=8$ & $n=8$ \\
Total collagen synthesis (nmol Pro incorporated into total Hyp) & $69.10 \pm 1.58$ & $117.11 \pm 2.76^{\ddagger}$ \\
Medium collagen accumulation (nmol Pro incorporated into protein-associated Hyp) & $32.28 \pm 0.65$ & $58.33 \pm 1.58^{\ddagger}$ \\
Medium collagen accumulation (nmol Pro incorporated into collagenase-sensitive protein) & $46.94 \pm 0.79$ & $89.37 \pm 2.78^{\ddagger}$ \\
Medium total protein accumulation (nmol Pro incorporated into Protein) & $166.6 \pm 10.5$ & $250.8 \pm 11.2^{\ddagger}$ \\
Medium fractional collagen accumulation (collagen formation as percentage of total protein) & $16.47 \pm 0.66$ & $18.96 \pm 0.39^{\S}$ \\
Cell layer collagen accumulation (nmol Pro incorporated into protein-associated Hyp) & $0.766 \pm 0.046$ & $1.286 \pm 0.09^{\|}$ \\
Total collagen catabolism (nmol Pro incorporated into free Hyp) & $36.05 \pm 1.14$ & $57.49 \pm 1.140^{\ddagger}$ \\
Fractional collagen catabolism (percentage of total collagen catabolized) & $52.11 \pm 0.63$ & $49.10 \pm 0.46^{9}$ \\
\hline
\end{tabular}

* Results were obtained after $48 \mathrm{~h}$ of incubation with $183 \mu \mathrm{M}$ radiolabeled proline. Incorporation data were corrected for the media specific radioactivity of the precursor and expressed per milligram of DNA/24 $\mathrm{h}$. Values are mean \pm SEM. Pro, proline; Hyp, 4-hydroxyproline. ${ }^{\ddagger} P<0.0001$; ${ }^{8} P=0.0056 ; \quad$ " $P=0.0002 ; \quad ' P=0.0017$.

Medium was regularly changed at 48 - $\mathrm{h}$ intervals during the period of cell growth. Subsequently, during the 3-d proline radiolabeling period, without replenishment of the medium, the MCGT1 cells demonstrated a 42-fold greater net glucose utilization (Table IV), which caused a decrease in the medium glucose concentration from $8 \mathrm{mM}$ to values $\sim 5 \mathrm{mM}$.

\section{Discussion}

In this work we have demonstrated that MCs overutilizing glucose synthesize and accumulate increased amounts of extracellular matrix even in the absence of elevated extracellular glucose concentrations. Clearly, it can be concluded from this finding that changes directly related to the presence of a high glucose concentration, i.e., extracellular hyperosmolarity and abnormally increased transmembrane gradients of glucose, are not necessarily required for the excessive formation of extracellular matrix by MCs in a diabetic milieu. This study suggests, instead, that the relevant factor is linked to metabolic changes occurring during the overutilization of glucose which follows its enhanced uptake. MCGT1 cells demonstrated a markedly increased transport of a glucose analog which was due to an increased $V_{\max }$ while affinity of the transporter remained unchanged. The measured $K_{\mathrm{m}}$ in MCGT1 cells and in their MCLacZ controls of 3.1$3.7 \mathrm{mM}$ is consistent with the values of $1-7 \mathrm{mM}$ determined by similar 2-deoxyglucose uptakes in multiple tissues for GLUT1 $(48,49)$. In conditions of $8 \mathrm{mM}$ glucose concentration, this transporter is, thus, fully saturated and any increases in uptake are expected to be mediated by the up-regulation of transporters. This suggests that under conditions of high glucose concentrations exaggerated glucose uptake and increased extracellular matrix synthesis may be related to increased expression of functional GLUT1.

The increased glucose uptake in MCGT1 cells was also accompanied by a high net utilization of glucose and an exaggerated formation of lactic acid and sorbitol. In addition, it was also associated with the accumulation of myo-inositol. Therefore, alterations related to myo-inositol depletion may be excluded as causative factors for the glucose-stimulated extracellular matrix formation.

Table IV. Collagen Metabolism and Glucose Utilization in MCGT1 or MCLacZ Exposed to Normal Glucose Concentrations*

\begin{tabular}{lrr}
\hline & MCLacZ & MCGT1 \\
\hline & $n=6$ & $n=6$ \\
Total collagen synthesis (nmol Pro incorporated into total Hyp) & $102.33 \pm 1.66$ & $214.37 \pm 4.49^{\ddagger}$ \\
Medium collagen accumulation (nmol Pro incorporated into protein-associated Hyp) & $23.37 \pm 0.41$ & $49.35 \pm 2.04^{\ddagger}$ \\
Medium collagen accumulation (nmol Pro incorporated into collagenase-sensitive protein) & $39.66 \pm 2.94$ & $86.06 \pm 6.01^{\ddagger}$ \\
Medium total protein accumulation (nmol Pro incorporated into protein) & $131.71 \pm 5.54$ & $238.16 \pm 8.69^{\ddagger}$ \\
Medium fractional collagen accumulation (collagen formation as percentage of total protein) & $15.14 \pm 0.43$ & $17.16 \pm 0.20^{\S}$ \\
Cell layer collagen accumulation (nmol Pro incorporated into protein-associated Hyp) & $1.419 \pm 0.046$ & $2.323 \pm 0.113^{\ddagger}$ \\
Total collagen catabolism (nmol Pro incorporated into free Hyp) & $77.53 \pm 1.32$ & $162.70 \pm 3.12^{\ddagger}$ \\
Fractional collagen catabolism (percentage of total collagen catabolized) & $75.73 \pm 0.25$ & $75.92 \pm 0.58$ \\
Net glucose utilization ( $\mu$ mol) & $2.69 \pm 6.51$ & $116.20 \pm 5.98^{\ddagger}$ \\
\hline
\end{tabular}

* Results were obtained after $72 \mathrm{~h}$ of incubation with $183 \mu \mathrm{M}$ radiolabeled proline. Incorporation data were corrected for the media specific radioactivity of the precursor and expressed per milligram of DNA/24 h. Values are mean \pm SEM. Pro, proline; Hyp, 4-hydroxyproline. ${ }^{\ddagger} P<0.0001 ;$ ${ }^{\S} P=0.0018$. 
The facilitative transporters involved in the energy-independent uptake of glucose comprise a group of integral membrane proteins, GLUT1-GLUT5, and GLUT7, which are encoded by separate genes. These proteins transport glucose with different efficiencies and kinetics (27). GLUT6 is a pseudogene, GLUT7 functions in the endoplasmic reticulum membrane, and GLUT5 is primarily an intestinal fructose transporter. The remaining GLUT isoforms, involved in the cellular transport of glucose, are expressed differently within tissues demonstrating distinct metabolism of this hexose, suggesting a close link between specific transporters and the handling of glucose through specific metabolic pathways (26). The insulin-regulatable GLUT4 isoform has been identified in MCs (50), however, its functional role remains in doubt since glucose transport and extracellular matrix synthesis in these cells do not appear to be influenced by insulin $(20,21)$. In this study, we confirm previous observations in tissue cultures and in renal histological specimens $(23,24)$ demonstrating the presence of GLUT1 in MCs.

To enhance glucose uptake we augmented the transport capacity by increasing the number of transporters. To this end, we transduced the $n e o^{\mathrm{R}}$ gene encoding neomycin phosphotransferase and human GLUT1 or bacterial LacZ (as control) in a cloned line of rat MCs. The resultant MCGT1 cells demonstrated a marked increase in GLUT1 synthesis as shown by the overexpression of GLUT1 mRNA and GLUT1 protein. The overexpression of LacZ or GLUT1 in the G418-resistant surviving clones was generalized to all cells and well maintained after multiple passages in culture. In cells such as 3T3-L1 adipocytes in which GLUT1 intrinsic activity appears to be modulated, the heterologous expression of human GLUT1 is also subject to the same inhibitory control (51). Therefore, it is expected that if the activity of the endogenous GLUT1 were regulated in MCs, the additional exogenous GLUT1 transporters expressed in our transduced cells would be under the same form of control.

The effect of high glucose concentrations on MC growth in tissue culture has been variously reported as being neutral (16, $21)$ or exerting inhibitory effects $(18,52)$. We observed decreased proliferation and cell hypertrophy in cultures of normal MCs exposed to $35 \mathrm{mM}$ glucose, according to the DNA and RNA/DNA values obtained at the end of the experimental period. Similar growth characteristics were demonstrated in a normal glucose environment by MCs overexpressing the GLUT1 transporter when compared to their LacZ-transduced controls. The mechanism by which this enhanced glucose uptake, whether elicited by increasing the extracellular concentration or by stimulating transport, may affect MC growth is not fully understood. However, it is likely that the process involves the induction of endogenous TGF- $\beta 1$ expression and/or activation (53). In long term cultures of MCs, high glucose concentrations stimulate TGF- $\beta 1$ secretion and cause sustained inhibition of cell proliferation, cell hypertrophy and increased protein synthesis $(53,54)$. These changes are prevented by neutralizing antibody against TGF- $\beta$ and they are not reproduced in an hyperosmolar environment obtained by the addition of L-glucose or mannitol (53).

We observed an increased cellular content of myo-inositol concomitant with the augmented glucose uptake and sorbitol accumulation in MCGT1 cells. This is an alteration similar to that seen in cells exposed to high glucose concentrations in which the $V_{\max }$ of the $\mathrm{Na}^{+}$-dependent myo-inositol cotransporter is increased $(55,56)$. Although the precise mechanism for this effect has not been elucidated, it involves stimulation of the polyol pathway and activation of protein kinase C. These two metabolic alterations are likely to be present in our MCGT1 cells (see below).

As shown in previous studies $(7,15-17,21)$, high concentrations of extracellular glucose increased net formation of collagen in the medium and in the cell layer in MC cultures. In addition, as demonstrated by others $(7,16)$, we identified an enhanced synthetic rate as the major metabolic alteration responsible for the accumulation of collagen. Contrary to other studies (15), however, we have observed associated changes in collagen catabolism and total protein synthesis. Collagen catabolism was accelerated by glucose, but this change was of insufficient magnitude to offset the markedly increased synthesis. In addition, protein secretion into the culture medium was also increased, although this change was of lesser magnitude than that for the accumulation of collagen. A possible cause for these discrepant results may be that, contrary to previous work, incorporation results in this study were corrected for changes in the sp act of the amino acid precursor.

The collagen metabolic changes shown in MCGT1 cells incubated in normal glucose conditions qualitatively mirrored those observed in normal MCs exposed to high glucose concentration. However, when compared to their corresponding controls, MCGT1 cells exhibited a greater increase in total collagen synthesis (109 vs 69\%) and in collagen accumulation (111$117 \%$ vs $81-90 \%$ ) than normal MCs incubated in high glucose conditions. All four of the individual matrix components examined in the culture medium, collagen I, collagen IV, fibronectin, and laminin, were increased 2.3- to 4.3-fold over values in MCLacZ cultures. In addition, the increased mRNAs for collagen I, collagen IV, and fibronectin is consistent with the increased synthesis of these individual matrix components. Total protein secretion was also enhanced, although not to the same extent as for collagen accumulation. Therefore, in terms of growth characteristics, myo-inositol accumulation and collagen metabolism, MCs overexpressing the GLUT1 transporter in an $8 \mathrm{mM}$ glucose environment behaved like normal MCs grown in $35 \mathrm{mM}$ glucose.

Recent studies have begun to unravel the mechanisms by which an increased entry of glucose into MCs may stimulate extracellular matrix formation. MCs grown in a high ambient glucose concentration demonstrate activation of protein kinase $\mathrm{C}$ as a result of increased diacylglycerol mass $(21,57)$. It has been proposed that protein kinase $C$ modulates activator protein 1 complex (AP-1), the transcriptional product of $j u n$ and $f o s$ protooncogenes, which in turn, binds to specific sequences in the promoter regions of extracellular matrix genes (58). This mechanism appears to be operative in vivo also, because diacylglycerol mass and protein kinase $\mathrm{C}$ activity are also increased in glomeruli from diabetic rats and in isolated normal glomeruli acutely exposed to high glucose concentrations (59). Since the change in diacylglycerol formation is through an enhanced de novo synthesis from glycolytic intermediates $(19,21,57)$ in a process favored by the altered cellular redox state caused by the increased polyol pathway activity, it follows that the stimulation of extracellular matrix synthesis requires the accelerated metabolism of glucose.

Our studies in transduced cells demonstrate that glucose transport is an important modulator in MCs for glucose utilization and for the glucose effects on extracellular matrix metabo- 
lism. In addition, the glucose-stimulated rate of extracellular matrix accumulation appears to depend to a greater degree on the capacity to transport glucose than on the actual extracellular concentration of the hexose. This underlines the potential importance of the regulation of GLUT1 expression and activity in MCs as a determinant of extracellular matrix deposition and mesangial expansion. Glucose flux via GLUT transporters may be regulated at the transcriptional level or by altering the rates of protein synthesis and degradation, changes in intrinsic activity, and the translocation of a vesicle-associated intracellular pool of transporters to the plasma membrane (26). The latter, while being paramount in the GLUT4 activation by insulin, is of lesser importance for GLUT1-mediated transport due to the already preponderant localization of this isoform on the plasma membrane under basal conditions and its lesser translocation efficiency (60). A large variety of agents regulate GLUT1 expression (27). In endothelial cells and hepatocytes hypoxia and inhibition of oxidative phosphorylation induce GLUT1 expression $(61,62)$. The most commonly reported effects of glucose have been those caused by its deprivation in both insulin-responsive and insulin-nonresponsive cells. These consist of changes in the transport of the hexose in association with increased GLUT1 protein, with or without associated changes in GLUT1 mRNA (25). These effects are readily reversed by providing glucose. In contrast, in the adipose tissue and skeletal muscle of hyperglycemic animals with streptozotocin-induced diabetes, GLUT1 mRNA and GLUT1 protein are inappropriately unaffected $(25,63)$.

The regulation of GLUT1 expression by growth factors is of particular importance as a potential element in the pathogenesis of diabetic mesangial expansion. PDGF and TGF- $\beta$ are known to enhance glucose uptake, increase GLUT1 mRNA and promote GLUT1 expression in cultures of fibroblast cell lines (64-68). MCs, in turn, produce PDGF and TGF- $\beta$ (67-70), thus having an autocrine system capable of regulating GLUT1 expression. This system may be activated in diabetes because high glucose concentrations increase the MC secretion of TGF$\beta$ and the expression of specific cellular receptors for this growth factor $(71,72)$. Furthermore, MCs respond to the same growth factors by increasing extracellular matrix formation in vitro $(72,73)$ and by inducing mesangial expansion and glomerulosclerosis in vivo $(74,75)$, but it is not known if GLUT1 overexpression participates in the mediation of this effect.

It is of interest that oral hypoglycemic agents, extensively used in the treatment of Type II diabetes, are highly effective in increasing GLUT1 expression and glucose transport. Metformin and the sulfonylureas tolbutamide and tolazamide increase GLUT1 protein, GLUT1 mRNA, and the translocation of this transporter to the plasma membrane in L6 myotubes and 3T3L1 adipocytes (76-79). The relative effect of metformin is particularly intense in conditions of high glucose concentrations (76). The relevance of these observations is tempered by the caution about extrapolating results in vitro with mechanisms in vivo. It could be speculated that the administration of these agents may result in the paradoxical circumstance in which an improvement in glycemia may be associated with greater glucose uptake and higher risk for the development of complications in GLUT1-expressing tissues. Whether this may occur in MCs is uncertain. There are many known examples of the tissue-specific regulation and expression of individual GLUT iso- forms $(26,80)$, and there is no present knowledge as to how this may proceed in MCs.

This work suggests that increased glucose uptake, rather than the level of glycemia per se, may be a major metabolic determinant in the development of mesangial expansion and glomerulosclerosis in diabetes. If MC GLUT1 expression and activity varies in human diabetes, this could explain the obscure predisposition of only a limited group of patients to the development of renal disease and the poor correlation between glycemic levels and progression of nephropathy in some of these cases, even after long periods of diabetes (81).

\section{Acknowledgments}

This work was supported in part by National Institutes of Health grants KO8 DK01953 and RO1 DK28081 awarded to Drs. Charles W. Heilig and Pedro Cortes, respectively, and by a grant from the Juvenile Diabetes Foundation International (\#1921461) awarded to Dr. Bruce L. Riser.

\section{References}

1. Bilous, R. W., S. M. Mauer, D. E. R. Sutherland, and M. W. Steffes. 1989. Mean glomerular volume and rate of development of diabetic nephropathy. Diabetes. 38:1142-1147.

2. Seyer-Hansen, K., J. Hansen, and H. J. G. Gundersen. 1980. Renal hypertrophy in experimental diabetes. A morphometric study. Diabetologia. 18:501-505.

3. Mauer, S. M., M. W. Steffes, E. N. Ellis, D. E. R. Sutherland, D. M. Brown and F. C. Goetz. 1984. Structural-functional relationships in diabetic nephropathy. J. Clin. Invest. 74:1143-1155.

4. Steffes, M. W., R. W. Bilous, D. E. R. Sutherland, and S. M. Mauer. 1992. Cell and matrix components of the glomerular mesangium in type I diabetes. Diabetes. 41:679-684.

5. Yaoita, E., K. Oguri, E. Okayama, K. Kawasaki, S. Kobayashi, I. Kihara, and M. Okayama. 1990. Isolation and characterization of proteoglycans synthetized by cultured mesangial cells. J. Biol. Chem. 265:522-531.

6. Scheinman, J. I., D. M. Brown, and A. F. Michael. 1978. Collagen synthesis by human glomerular cells in culture. Biochem. Biophys. Acta. 542:128-136.

7. Ayo, S. H., R. A. Radnik, J. A. Garoni, W. F. Glass II, and J. I. Kreisberg. 1990. High glucose causes an increase in extracellular matrix proteins in cultured mesangial cells. Am. J. Pathol. 136:1339-1348.

8. Riser, B. L., P. Cortes, X. Zhao, J. Bernstein, F. Dumler, and R. G. Narins. 1992. Intraglomerular pressure and mesangial stretching stimulate extracellular matrix formation in the rat. J. Clin. Invest. 90:1932-1943.

9. Okuda, S., L. R. Languino, E. Ruoslahti, and W. A. Border. 1990. Elevated expression of transforming growth factor $\beta$ and proteoglycan production in experimental glomerulonephritis. Possible role in expansion of the mesangial extracellular matrix. J. Clin. Invest. 86:453-462.

10. Bilous, R. W., S. M. Mauer, D. E. R. Sutherland, J. S. Najarian, F. C Goetz, and M. W. Steffes. 1989. The effects of pancreas transplantation on the glomerular structure of renal allografts in patients with insulin-dependent diabetes. N. Engl. J. Med. 321:80-85.

11. Barbosa, J., M. W. Steffes, D. E. R. Sutherland, J. E. Connet, K. V. Rao, and S. M. Mauer. 1994. Effect of glycemic control on early diabetic renal lesions. A 5-year randomized controlled clinical trial of insulin-dependent diabetic kidney transplant recipients. J. Am. Med. Assoc. 272:600-606.

12. Rash, R. 1979. Prevention of diabetic glomerulopathy in streptozotocin diabetic rats by insulin treatment. The mesangial regions. Diabetologia. 17:243248.

13. Steffes, M. W., D. M. Brown, J. M. Basgen, and S. M. Mauer. 1980 Amelioration of mesangial volume and surface alterations following islet transplantation in diabetic rats. Diabetes. 29:509-515.

14. Petersen, J., J. Ross, and R. Rabkin. 1988. Effect of insulin therapy on established diabetic nephropathy in rats. Diabetes. 37:1346-1350.

15. Ayo, S. H., R. A. Radnick, W. F. Glass II, J. A. Garoni, E. R. Rampt, D. R. Appling, and J. I. Kreisberg. 1991. Increased extracellular matrix synthesis and mRNA in mesangial cells grown in high glucose medium. Am. J. Physiol. 260 (Renal Fluid Electrolyte Physiol. 29):F185-F191.

16. Danne, T., M. J. Spiro, and R. G. Spiro. 1993. Effect of high glucose on type IV collagen production by cultured glomerular epithelial, endothelial, and mesangial cells. Diabetes. 42:170-177.

17. Haneda, M., R. Kikkawa, N. Horide, M. Togawa, D. Koya, N. Kajiwara, A. Ooshima, and Y. Shigeta. 1991. Glucose enhances type IV collagen production in cultured rat glomerular mesangial cells. Diabetologia. 34:198-200. 
18. Nahman, N. S. Jr., K. L. Leonhart, F. G. Cosio, and C. L. Hebert. 1992. Effects of high glucose on cellular proliferation and fibronectin production by cultured human mesangial cells. Kidney Int. 41:396-402.

19. Studer, R., P. A. Craven, and F. R. DeRubertis. 1993. Role for protein kinase $\mathrm{C}$ in the mediation of increased fibronectin accumulation by mesangial cells grown in high-glucose medium. Diabetes. 42:118-126.

20. Fumo, P., G. S. Kuncio, and F. N. Ziyadeh. 1994. PKC and high glucose stimulate collagen $\alpha_{1}$ (IV) transcriptional activity in a reporter mesangial cell line. Am. J. Physiol. 267 (Renal Fluid Electrolyte Physiol. 36):F632-F638.

21. Kreisberg, J. I., and S. H. Ayo. 1993. The glomerular mesangium in diabetes mellitus. Kidney Int. 43:109-113.

22. Kreisberg, J. I. 1992. Hyperglycemia and microangiopathy. Direct regulation by glucose of microvascular cells. Lab. Invest. 67:416-426.

23. Kikkawa, R., N. Kajiwara, M. Haneda, Y. Shigeta, K. Tsuda, H. Yano, and Y. Seino. 1992. Glut 1 is a main glucose transporter in rat mesangial cells. $J$. Am. Soc. Nephrol. 3:830a. (Abstr.)

24. Heilig, C. W., B. Riser, S. Sastry, and P. Cortes. 1992. Identification of facilitative glucose transporters (GT) in mesangial cells (MC). J. Am. Soc. Nephrol. 3:758a. (Abstr.)

25. Klip, A., T. Tsakiridis, A. Marette, and P. A. Ortiz. 1994. Regulation of expression of glucose transporters by glucose: a review of studies in vivo and in cell cultures. FASEB (Fed. Am. Soc. Exp. Biol.) J. 8:43-53.

26. Kahn, B. B. 1992. Facilitative glucose transporters: regulatory mechanisms and dysregulation in diabetes. J. Clin. Invest. 89:1367-1374.

27. Baldwin, S. A. 1993. Mammalian passive glucose transporters: members of a ubiquitous family of active and passive transport proteins. Biochem. Biophys. Acta. 1154:17-49.

28. Harrison, S. A., J. M. Buxton, and M. P. Czech. 1991. Suppressed intrinsic catalytic activity of GLUT1 glucose transporters in insulin-sensitive 3T3-L1 adipocytes. Proc. Natl. Acad. Sci. USA. 88:7839-7843.

29. Harrison, S. A., J. M. Buxton, B. M. Clancy, and M. P. Czech. 1990. Insulin regulation of hexose transport in mouse 3T3-L1 cells expressing the human HepG2 glucose transporter. J. Biol. Chem. 265:20106-20116.

30. Mueckler, M., C. Caruso, S. A. Baldwin, M. Panico, I. Belch, H. R. Morris, W. J. Allard, G. E. Lienhard, and H. F. Lodish. 1985. Sequence and structure of a human glucose transporter. Science (Wash. DC). 229:941-945.

31. Freytag, S. O., D. L. Paielli, and J. D. Gilbert. 1994. Ectopic expression of the CCAAT/enhancer-binding protein $\alpha$ promotes the adipogenic program in a variety of mouse fibroblastic cells. Genes \& Dev. 8:1654-1663.

32. Dumler, F., and P. Cortes. 1988. Uracil ribonucleotide metabolism in rat and human glomerular epithelial and mesangial cells. Am. J. Physiol. 255 (Cell Physiol. 24):C712-C718.

33. Varani, J., C. G. Taylor, B. L. Riser, D. K. Schumaker, K.-Y. Yeh, M Dame, D. F. Gibbs, R. F. Todd III, F. Dumler, J. Bromberg, and P. D. Killen. 1992 Mesangial cell killing by leukocytes: role of leukocyte oxidants and proteolytic enzymes. Kidney Int. 42:1169-1177.

34. Freytag, S., and T. Geddes. 1992. Reciprocal regulation of adipogenesis by Myc and C/EBP $\alpha$. Science (Wash. DC). 256:379-382.

35. Bosh, R. J., A. S. Woolf, and L. G. Fine. 1993. Gene transfer into the mammalian kidney: direct retrovirus-transduction of regenerating tubular epithelial cells. Exp. Nephrol. 1:49-54.

36. Sharp, P. A., A. J. Berk, and S. M. Berget. 1980. Transcription maps of adenovirus. Methods Enzymol. 65:750-768.

37. Phan, S. M., J. Varani, and D. Smith. 1985. Rat lung fibroblast collagen metabolism in bleomycin-induced pulmonary fibrosis. J. Clin. Invest. 76:241 247.

38. Munro, H. N., and A. Fleck. 1966. The determination of nucleic acids Methodol. Surv. Biochem. Anal. 12:113-176.

39. McClain, D. A., H. Maegawa, J. Lee, T. J. Dull, A. Ulrich, and J. M. Olefsky. 1987. J. Biol. Chem. 262:14663-14671.

40. Al-Nawab, M. D., and D. R. Davies. 1993. Demonstration of extracellular immunoglobulin in renal tissues with silver enhanced colloidal gold. J. Histotech nol. 16:235-242.

41. Weissbach, A. 1974. myo-Inositol assay. In Methods of Enzymatic Analysis. H. U. Bergmeyer, editor. Academic Press, Inc., New York. 1333-1336.

42. Bergmeyer, H. U., W. Gruber, and I. Gutmann. D-Sorbitol assay. 1974. In Methods of Enzymatic Analysis. H. U. Bergmeyer, editor. Academic Press, Inc., New York. 1323-1326.

43. Cortes, P., F. Dumler, K. S. S. Sastry, C. P. Verghese, and N. W. Levin. 1982. Effects of early diabetes on uridine diphosphosugar synthesis in the rat renal cortex. Kidney Int. 21:676-682.

44. Tsanev, R., and G. Markov. 1960. Substances interfering with spectrophotometric estimation of nucleic acids and their elimination by the two-wavelength method. Biochim. Biophys. Acta. 42:442-452.

45. Doi, E. T., D. Shibata, and T. Matoba. 1981. Modified colorimetric ninhydrin method for peptidase assay. Anal. Biochem. 118:173-184.

46. Haverty, T. P., C. J. Kelly, J. R. Hoyer, R. Alvarez, and E. G. Neilson. 1992. Tubular antigen-binding proteins repress transcription of type IV collagen in the autoimmune target epithelium of experimental interstitial nephritis. J. Clin. Invest. 89:517-523.

47. Olsen, D. R., J. Peltonen, S. Jaakkola, M. Chu, and J. Uitto. 1989. Collagen gene expression by cultured human skin fibroblasts. J. Clin. Invest. 83:791-795.

48. Thorens, B., M. J. Charron, and H. F. Lodish. 1990. Molecular physiology of glucose transporters. Diabetes Care. 13:209-218.

49. Gould, G. W., and G. D. Holman. 1993. The glucose transporter family: structure, fuction and tissue-specific expression. Biochem. J. 295:329-341.

50. Brosius III, F. C., J. P. Briggs, R. G. Marcus, M. Barac-Nieto, and M. J. Charron. Insulin-responsive glucose transporter expression in renal microvessels and glomeruli. Kidney Int. 42:1086-1092.

51. Harrison, S. A., J. M. Buxton, and M. P. Czech. 1991. Suppressed intrinsic catalytic activity of GLUT1 glucose transporters in insulin-sensitive 3T3-L1 adipocytes. Proc. Natl. Acad. Sci. USA. 88:7839-7843.

52. Moran, A., D. M. Brown, Y. Kim, and D. J. Klein. 1991. Effects of IGF1 and glucose on protein and proteoglycan synthesis by human fetal mesangial cells in culture. Diabetes. 42:170-177.

53. Wolf, G., K. Sharma, Y. Chen, M. Ericksen, and F. N. Ziyadeh. 1992. High glucose-induced proliferation in mesangial cells is reversed by autocrine TGF $\beta$. Kidney Int. 42:647-656.

54. Choi, M. E., E.-G. Kim, Q. Huang, and B. J. Ballermann. 1993. Rat mesangial cell hypertrophy in response to transforming growth factor- $\beta 1$. Kidney Int. 44:948-958.

55. Guzman, N. J., and F. T. Crews. 1992. Regulation of inositol transport by glucose and protein kinase $C$ in mesangial cells. Kidney Int. 42:33-40.

56. Chatzilias, A. E., and C. I. Whiteside. 1994. Cellular mechanisms of glucose-induced myo-inositol transport upregulation in rat mesangial cells. Am. J. Physiol. 267 (Renal Fluid Electrolyte Physiol. 36):F459-F466.

57. Ayo, S. H., R. Radnik, J. A. Garoni, D. A. Troyer, and J. I. Kreisberg. 1991. High glucose increases diacylglycerol mass and activates protein kinase $\mathrm{C}$ in mesangial cell cultures. Am. J. Physiol. 261 (Renal Fluid Electrolyte Physiol. 30):F571-F577.

58. Kreisberg, J. I., R. A. Radnik, S. H. Ayo, J. A. Garoni, and P. Saikumar. 1994. High glucose elevates c- fos and c-jun transcripts and proteins in mesangial cell cultures. Kidney Int. 46:105-112.

59. Craven, P., and F. R. DeRubertis. 1989. Protein kinase C is activated in glomeruli from streptozotocin diabetic rats. Possible mediation by glucose. $J$. Clin. Invest. 83:1667-1675.

60. Marette, A., J. M. Richardson, T. Ramlal, T. W. Balon, M. Vranic, J. E. Pessin, and A. Klip. 1992. Abundance, localization, and insulin-induced translocation of glucose transporters in red and white muscle. Am. J. Physiol. 263 (Cell Physiol. 32):C443-C452.

61. Shetty, M., N. Ismail-Beigi, J. N. Loeb, and F. Ismail-Beigi. 1993. Induction of GLUT1 mRNA in response to inhibition of oxidative phosphorylation. Am. J. Physiol. 265 (Cell Physiol. 34):C1224-C1229.

62. Loike, J. D., L. Cao, J. Brett, S. Ogawa, S. C. Silverstein, and D. Stern. 1992. Hypoxia induces glucose transporter expression in endothelial cells. Am. J. Physiol. 236 (Cell Physiol. 32):C326-C333.

63. Sivitz, W. I., S. L. DeSautel, T. Kayano, G. I. Bell, and J. E. Pessin. 1989. Regulation of glucose transporter messenger RNA in insulin-deficient states. Nature (Lond.). 340:72-74.

64. Inman, W. H., and S. P. Colowick. 1985. Stimulation of glucose uptake by transforming growth factor $\beta$ : evidence for the requirement of epiderma growth factor-receptor activation. Proc. Natl. Acad. Sci. USA. 82:1346-1349.

65. Hiraki, Y., O. M. Rosen, and M. J. Birnbaum. 1988. Growth factors rapidly induce expression of the glucose transporter gene. J. Biol. Chem. 263:13655-13662.

66. Rollins, B. J., E. D. Morrison, P. Usher, and J. S. Flier. 1988. Plateletderived growth factor regulates glucose transporter expression. J. Biol. Chem. 236:16523-16526.

67. Kitagawa, T., M. Tanaka, and Y. Akamatzu. 1989. Regulation of glucose transport activity and expression of glucose transporter mRNA by serum, growth factors and phorbol ester in quiescent mouse fibroblasts. Biochem. Biophys. Acta. 980:100-108.

68. Merrall, N. W., M. J. O. Wakelam, R. Plevin, and G. W. Gould. 1993. Insulin and platelet-derived growth factor acutely stimulate glucose transport in 3T3-L1 fibroblasts independently of protein kinase C. Biochem. Biophys. Acta. 1177:191-198

69. Abboud, H. E., E. Poptic, and P. DiCorleto. 1987. Production of plateletderived growth factorlike protein by rat mesangial cells in culture. J. Clin. Invest. 80:675-683.

70. Kaname, S., S. Uchida, E. Ogata, and K. Kurokawa. 1992. Autocrine secretion of transforming growth factor- $\beta$ in cultured rat mesangial cells. Kidney Int. 42:1319-1327.

71. Ladson-Wofford S. B. L. Riser, and P. Cortes. 1994. High extracellular glucose concentrations increase receptors for transforming growth factor- $\beta$ $(\mathrm{TGF} \beta$ ) in rat mesangial cells (MC) in culture. J. Am. Soc. Nephrol. 5:696a. (Abstr.) 
72. Ziyadeh, F. N., K. Sharma, M. Ericksen, and G. Wolf. 1994. Stimulation of collagen gene expression and protein synthesis in murine mesangial cells by high glucose is mediated by autocrine activation of transforming growth factorB. J. Clin. Invest. 93:536-542.

73. Abboud, H. E. 1992. Platelet-derived growth factor and mesangial cells. Kidney Int. 41:581-583.

74. Floege, J., E. Eng, B. A. Young, C. E. Alpers, T. B. Barret, D. F. BowenPope, and R. J. Johnson. 1993. Infusion of platelet-derived growth factor or basic fibroblast growth factor induces selective glomerular mesangial cell proliferation and matrix accumulation in rats. J. Clin. Invest. 92:2952-2962.

75. Isaka, Y., Y. Fujiwara, N. Ueda, Y. Kaneda, T. Kamada, and E. Imai. 1993. Glomerulosclerosis induced by in vivo transfection of transforming growth factor- $\beta$ or platelet-derived growth factor gene into the rat kidney. J. Clin. Invest. 92:2597-2601.

76. Sarabia, V., L. Lam, E. Burdett, L. A. Leiter, and A. Klip. 1992. Glucose transport in human skeletal muscle cells in culture. Stimulation by insulin and metformin. J. Clin. Invest. 90:1386-1395.

77. Hundal, H. S., T. Ramlal, R. Reyes, L. A. Leiter, and A. Klip. 1992.
Cellular mechanism of metformin action involves glucose transporter translocation from an intracellular pool to the plasma membrane in L6 muscle cells. Endocrinology. 131:1165-1173.

78. Tordjman, K. M., K. A. Leingang, D. E. James, and M. M. Mueckler. 1989. Differential regulation of two distinct glucose transporters species expressed in 3T3-L1 adipocytes: Effect of chronic insulin and tolbutamide treatment. Proc. Natl. Acad. Sci. USA. 86:7761-7765.

79. Wang, P. H., D. Moller, J. S. Flier, R. C. Nayak, and R. J. Smith. 1989. Coordinate regulation of glucose transporter function, number, and gene expression by insulin and sulfonylureas in L6 rat skeletal muscle cells. J. Clin. Invest. 84:62-67.

80. Kaiser, N., S. Sasson, E. P. Feener, N. Boukobza-Vardi, S. Higashi, D. E. Moller, S. Davidheiser, R. J. Przybylski, and G. L. King. 1993. Differential regulation of glucose transport and transporters by glucose in vascular endothelial and smooth muscle cells. Diabetes. 42:80-89.

81. Gilbert, R. E., C. Tsalamandris, L. A. Batch, S. Panagiotopoulos, R. C. O'Brien, T. J. Allen, I. Goodall, V. Young, E. Seeman, R. M. L. Murray, et al. 1993. Long-term glycemic control and the rate of progression of early diabetic kidney disease. Kidney Int. 44:855-859. 